\title{
cAMP-independent signaling regulates steroidogenesis in mouse Leydig cells in the absence of StAR phosphorylation
}

\author{
Pulak R Manna, Syam P Chandrala, Youngah Jo and Douglas M Stocco \\ Department of Cell Biology and Biochemistry, Texas Tech University Health Sciences Center, Lubbock, Texas 79430, USA \\ (Requests for offprints should be addressed to D M Stocco; Email: doug.stocco@ttuhsc.edu)
}

\begin{abstract}
In the regulation of steroid biosynthesis, a process mediated by the steroidogenic acute regulatory (StAR) protein, both cAMP-dependent and -independent pathways are involved. While the cAMP-dependent regulatory events represent, by far, the most robust increase in steroid synthesis and are well established, the knowledge regarding cAMP-independent mechanisms is lacking. The present investigation was designed to elucidate the potential involvement of the latter in regulating StAR expression and steroidogenesis in mouse Leydig tumor cells ( $\mathrm{mLTC}-1$ cells). Treatment of mLTC-1 cells with a number of factors including insulin-like growth factor-I (IGF-I), epidermal growth factor (EGF), fibroblast growth factor, transforming growth factor (TGF) $\alpha$, interleukin-1 (IL-1), and colony-stimulating factor-1, increased the levels of StAR mRNA, StAR protein, and progesterone to varying degrees and utilized signaling pathways that are not associated with elevations in intracellular cAMP levels. Importantly, phosphorylation of StAR in response to these stimuli was undetectable, which is in marked contrast to observations with human chorionic gonadotropin (hCG), indicating factors that do not alter intracellular cAMP, regulate the steroid biosynthesis in a StAR phosphorylation-independent manner. In addition, the roles for factors involved in cross-talk between the protein kinase pathways, PKA and PKC, were demonstrated. Further characterization of signaling by one such cAMP-independent factor, TGF $\alpha$, demonstrated that the mechanism, whereby it increased StAR expression and steroid synthesis, was dependent on de novo protein synthesis and mediated via activation of the EGF receptor. TGF $\alpha$ was also able to augment hCG-stimulated cAMP synthesis, StAR protein and StAR phosphorylation, and influence hCG binding and LH receptor mRNA expression. Furthermore, TGF $\alpha$ increased phosphorylation of extracellular signal-regulated kinases 1/2 (ERK1/2) and cAMP-response element-binding protein (CREB), processes inhibited by the mitogen-activated protein kinase/ERK inhibitor U0126 and by expression of non-phosphorylatable CREB-M1 respectively. Inhibition of ERK activity enhanced TGF $\alpha$-mediated StAR protein expression (but not its phosphorylation) and decreased progesterone synthesis, events correlated with the expression of dosage-sensitive sex reversal, adrenal hypoplasia congenita, critical region on the X chromosome, gene 1 (DAX-1) and scavenger receptor class B type 1 (SR-B1). Collectively, these findings demonstrate that, in mouse Leydig cells, cAMPindependent signaling events regulate steroidogenesis in a StAR phosphorylation-independent manner.
\end{abstract}

Journal of Molecular Endocrinology (2006) 37, 81-95

\section{Introduction}

Regulation of various Leydig cell functions, including steroidogenesis, are predominantly mediated by luteinizing hormone/chorionic gonadotropin (LH/CG) through the involvement of multiple signaling pathways (Dufau 1988, Cooke et al. 1992, Saez 1994, Ascoli et al. 2002, Stocco et al. 2005). The steroidogenic responsiveness of Leydig cells has been shown to be regulated not only by LH/CG but also by peptide and non-peptide hormones, including locally produced factors, prostaglandins, and steroids through endocrine, paracrine, and autocrine events (Saez 1994, Cooke 1999, Stocco et al. 2005). A substantial amount of evidence indicates that the testis produces a variety of regulatory molecules that influence steroidogenesis through local control systems and LH/CG actions are also under the control of many of these factors (Ascoli \& Segaloff 1989, Saez 1994, Cooke 1999). It is noteworthy, however, that regulation of steroidogenesis involves both cAMPdependent and -independent signaling. While the role of the former signaling cascade in steroidogenesis is well established, regulatory mechanisms involved in cAMP-independent events remain obscure.

The steroidogenic acute regulatory (StAR) protein mediates the rate-limiting and regulated step in steroid hormone biosynthesis, i.e. the delivery of cholesterol from the outer to the inner mitochondrial membrane (Clark et al. 1994, Lin et al. 1995, Stocco \& Clark 1996). Both basic and clinical studies have provided compelling evidence regarding the role of StAR in regulating steroidogenesis (Bose et al. 1996, Caron et al. 1997, Miller \& Strauss 1999, Hasegawa et al. 2000, Stocco 2002), and striking correlations between the syntheses of steroids and StAR have been demonstrated (Clark et al. 1995, Stocco \& Clark 1996, Manna et al. 1999a, Schwarzenbach et al. 2003, Manna \& Stocco 2005). Studies have identified two putative protein kinase (PKA) 
phosphorylation sites at Ser56/57 and Ser194/195, in murine and human StAR respectively, and the importance of the latter site in obtaining maximal steroidproducing activity of StAR has been demonstrated (Arakane et al. 1997, Jo et al. 2005, Manna et al. 2006). Given the importance of the StAR protein and to further understand its role in regulating steroid biosynthesis, an investigation of cAMP-independent signaling in steroidogenesis is warranted.

Several lines of evidence indicate that cytokines and growth factors are capable of regulating the Leydig cell steroidogenic machinery in a typically cAMP-independent manner (Ascoli et al. 1987, Saez 1994, Lin et al. 1998, Cooke 1999, Manna et al. 2002a, 2006, Stocco et al. 2005), although the effect of each of the factors differs depending on the specific parameter being determined. While the cAMP signal transduction pathway is unquestionably the major signaling cascade in the regulation of steroidogenesis and StAR expression, several other intracellular events have been demonstrated to be instrumental in this process (reviewed in Refs. Cooke (1999), Manna \& Stocco (2005) and Stocco et al. (2005)). These studies demonstrated that the protein kinase $\mathrm{C}$ (PKC) signaling plays an important role in regulating StAR expression and steroidogenesis (Pilon et al. 2003, Jo et al. 2005), as has the mitogen-activated protein kinase (MAPK) family of Ser-Thr kinases (Gyles et al. 2001, Seger et al. 2001, Manna et al. 2002a, Martinelle et al. 2004, Martinat et al. 2005). In addition, StAR's transcriptional regulation has been shown to be mediated by several transcription factors, including the cAMP-response element-binding protein (CREB) and dosage-sensitive sex reversal, adrenal hypoplasia congenita, critical region on the $\mathrm{X}$ chromosome, gene 1 (DAX-1) (Manna et al. 2002b, 2006, Jo \& Stocco 2004, Clem et al. 2005). In addition, the scavenger receptor class B type 1 (SR-B1), a high-density lipoprotein receptor, was shown to be involved in regulating steroidogenesis by facilitating the mobilization of precursor cholesterol into steroidogenic cells (Rao et al. 2003, Manna et al. 2006).

In the present study, the role of cAMP-independent events in the regulation of StAR expression and steroidogenesis was assessed, emphasizing the role of transforming growth factor (TGF $\alpha$ ), a growth factor produced within the testis, and binds to the EGF receptor (EGFR) and exerts effects on proliferation and differentiation via the EGFR (Saez 1994, Schroeder \& Lee 1997, Millena et al. 2004). These studies have been performed utilizing the mLTC-1 mouse Leydig tumor cell line (Rebois 1982), a cell line which possesses several characteristics of its normal counterparts, including the secretion of testosterone (Panesar et al. 2003, Panesar \& Chan 2004, Manna et al. 2006).

\section{Materials and methods}

\section{Plasmids, transfections, and reporter assays}

The 5'-flanking -966/-1 bp region of the mouse StAR gene (in relation to the transcription start site) was cloned into the pGL3 basic vector (Promega), upstream of a luciferase reporter gene, utilizing the XhoI and HindIII sites (Manna et al. 2002b, 2003). The identity of the inserted fragment was tested by restriction endonuclease digestion and by automated sequencing with a Perkin-Elmer Biosystem 310 Genetic Analyzer (ABI PRISM 310; Perkin-Elmer, Norwalk, CT, USA). Expression plasmids for wild-type CREB (WT-CREB) and non-phosphorylatable CREB (CREB-M1, Ser ${ }^{133-}$ Ala) have been previously described (Manna et al. 2002b). The plasmid (pRL-SV40) containing the Renilla luciferase gene driven by the SV40 promoter (Promega) was used to normalize the transfection efficiency.

Mouse Leydig tumor cells (mLTC-1; (Rebois 1982)) (The American Type Culture Collection, Rockville, MD, USA) were maintained in Roswell Park Memorial Institute (RPMI) medium supplemented with $10 \%$ fetal bovine serum (Life Technologies) containing antibiotics (Manna et al. 2002b). Transfection studies were carried out using FuGENE 6-transfection reagent (Roche) under optimized conditions (Manna et al. 2003). Briefly, cells were cultured either in 12- or 6-well plates to $65-75 \%$ confluence, transfected using 1-2 $\mu \mathrm{g}$ plasmid in the presence of 12-20 ng pRL-SV40 and utilized for treatments following $36 \mathrm{~h}$ of transfection.

Luciferase activity in the cell lysates was determined by the Dual-luciferase reporter assay (Promega). After treatments with different factors, 200-275 $\mu \mathrm{l}$ of the reporter lysis buffer was added to the plates and the supernatants were measured for relative light units (luciferase/renilla) in a TD 20/20 Luminometer (Turner Designs, Sunnyvale, CA, USA).

\section{Immunoblotting}

Immunoblotting studies were carried out using either mitochondrial or total cellular protein, as described previously (Clark et al. 1994, Manna et al. 2002a). In brief, mitochondrial or cellular protein $(20-30 \mu \mathrm{g})$ was solubilized in sample buffer $(25 \mathrm{mmol} / \mathrm{l}$ Tris-Cl, $\mathrm{pH}$ $6 \cdot 8,1 \%$ SDS, $5 \%$-mercaptoethanol, $10 \%$ glycerol, and $0.01 \%$ bromophenol blue) and loaded onto a SDS- $12 \%$ PAGE gel (Mini Protean II System, BioRad), as described by Laemmli (1970), with minor modifications (Manna et al. 2002a, 2006). Electrophoresis was performed at $200 \mathrm{~V}$ for $1 \mathrm{~h}$ and the proteins were transferred electrophoretically onto Immuno-Blot polyvinylidene fluoride membranes (BioRad). The membranes were incubated overnight at $4{ }^{\circ} \mathrm{C}$ in blocking buffer (Tris-buffered saline containing $0 \cdot 2 \%$ Tween-20 
and $4 \%$ Carnation non-fat dry milk) and incubated for $2 \mathrm{~h}$ with primary antibodies (Abs) for StAR protein (Bose et al. 1999) and phospho-StAR protein (a gift from Dr SR King, Baylor College of Medicine, Houston, TX, USA (Jo et al. 2005, Manna et al. 2006)). It should be noted that the former $\mathrm{Ab}$ cannot distinguish between non-phosphorylated and phosphorylated StAR and hence, it detects total StAR protein. Other Abs utilized in immunoblotting were obtained from the following sources: cytochrome $\mathrm{P} 450$ cholesterol sidechain cleavage (P450scc) (Chemicon International Inc., Temecula, CA, USA), phospho-extracellular signal-regulated kinases $1 / 2$ (ERK1/2), phosphoCREB and CREB (Cell Signaling Technology, Beverly, MA, USA), ERK1/2 (BD Biosciences Pharmingen, San Diego, CA, USA), actin (Santa Cruz Biotechnology, Inc., Santa Cruz, CA, USA), 3 $\beta$-hydroxysteroid dehydrogenase (3ß-HSD, a gift from Dr CR Parker, University of Alabama at Birmingham, Birmingham, AL, USA) and DAX-1 (a gift from Dr P. Sassone-Corsi, Université Louis Pasteur, Strasbourg, France). Following incubation with the primary Abs, the membranes were washed and incubated with secondary Abs for $1.5 \mathrm{~h}$, washed again, and the immunodetection of proteins was performed with a Chemiluminescence Imaging Western Lightning Kit (Perkin-Elmer, Boston, MA, USA). The membranes were exposed to X-ray film (Marsh Bio Products, Inc., Rochester, NY, USA) and the intensity of immunospecific bands was quantified using a computer-assisted image analyzer (Visage 2000, Ann Arbor, MI, USA).

\section{Quantitative reverse transcriptase (RT)-PCR}

Total RNA from different treatment groups was extracted using Trizol reagent (Invitrogen). RT and PCR were run sequentially in the same assay tube using $2 \mu \mathrm{g}$ total RNA, as described previously (Manna et al. 1999a, 2006). Briefly, StAR and SR-B1 cDNAs were amplified using the following primer pairs: StAR sense, 5'-GACCTTGAAAGGCTCAGGAAGAAC- $3{ }^{\prime}$, and, StAR antisense, $5^{\prime}$ TAGCTGAAGATGGACAGACTTGC- $3^{\prime}$ and SR-BI sense, 5'-CTCATCCAAGCAGCAGGTGCTCAAGAA-3' and, SR-BI antisense, 5'-TGTTTGCCAACGGGTCCGTCTACCCACC-3' respectively. The L19 ribosomal protein gene was used as an internal control, using the sense primer $5^{\prime}$-GAAATCGCCAATGCCAACTC- $3^{\prime}$ and the antisense primer $5^{\prime}$-TCTTAGACCTGCGAGCCTCA-3' ${ }^{\prime}$. The cDNAs generated were further amplified by PCR using the primer pairs listed previously. The molecular sizes of StAR, SR-B1 and L19 were determined on $1 \cdot 2 \%$ agarose gels, which were then vacuum dried and exposed to X-ray film (Marsh Bio Products) for 1-2 h. The levels of StAR, SR-B1, and L19 signals were quantified using the Visage 2000.

\section{Path-detect Elk1 trans-reporting assay}

mLTC-1 cells were transfected with the Elk1 transreporting system (Stratagene, La Jolla, CA, USA), which includes a pathway-specific fusion trans-activator plasmid (pFA2-Elk1) that expresses a fusion protein (Manna et al. 2002a). The fusion trans-activator protein consists of the activation domain of Elk1 (amino acid (aa) 307-427) fused with the yeast GAL4 DNA-binding domain (dbd, aa 1-147), which is driven by a cytomegalovirus promoter. The pFR-Luc reporter plasmid contains a synthetic promoter of the yeast Gal4-binding sites that control expression of the firefly luciferase gene. The pFC2-dbd is a negative control for the pFA2 plasmid that lacks the activation domain of Elk1. Upon co-transfection, the DNA binding domain (dbd) of the fusion trans-activator protein binds to the reporter plasmid at the Gal4-binding sites and phosphorylation of the transcription activation domain of the fusion trans-activator protein by different factors will activate transcription of the luciferase gene, indicating the involvement of the MAPK pathway. Following $36 \mathrm{~h}$ of transfection, cells were stimulated for $6 \mathrm{~h}$ with different factors as indicated, and the luciferase activity in the cell lysates was determined using a TD 20/20 luminometer (Turner Designs).

\section{$\left[{ }^{125} \mathrm{I}\right]$-human chorionic gonadotropin (hCG)-binding studies}

$\left[{ }^{125} \mathrm{I}\right]$-hCG binding was carried out in intact mLTC-1 cells, as previously described (Manna et al. 2002a), using radio-iodinated hCG with a specific activity of $50 \mu \mathrm{Ci} / \mu \mathrm{g}$ (Perkin-Elmer). Cells were stimulated for $0-24 \mathrm{~h}$ with TGF $\alpha$, and $2 \cdot 5-3 \cdot 0 \times 10^{5}$ cells were incubated with $\left[{ }^{125} \mathrm{I}\right]$-hCG $(\sim 100000 \mathrm{cpm})$ either in the absence (total) or presence (non-specific) of $250 \mathrm{ng}$ unlabeled hCG (Sigma). Following $16 \mathrm{~h}$ of incubation, the reaction was terminated by the addition of $3 \mathrm{ml}$ of ice-cold phosphate-buffered saline (PBS) containing $0 \cdot 1 \%$ BSA. After centrifugation, the supernatant was discarded and radioactivity in the pellet was determined using a gamma counter (1277 Gammamaster, LKB Wallac Oy, Finland).

\section{Northern hybridization analysis}

Total RNA (15-20 $\mu \mathrm{g})$ isolated from different treatment groups was resolved on $1.2 \%$ formaldehyde denaturing agarose gels and transferred onto nylon membranes (Hybond- ${ }^{+}$, Amersham). An antisense cRNA probe to an extracellular part of the rat LHR (441-849 bp) was produced by in vitro transcription using a riboprobe synthesis kit (Promega), dNTPs, and $\left[\alpha-{ }^{32} \mathrm{P}\right]-\mathrm{UTP}$ $(800 \mathrm{Ci} / \mathrm{mmol}$, Amersham). Prehybridization, hybridization, and washing of the membranes were carried out 
under stringent conditions, as described previously (Manna et al. 2001, 2002a). To evaluate variation in LHR mRNA expression, the membranes were re-hybridized with a cDNA probe for glyceraldehyde-3phosphate dehydrogenase (GAPDH). The membranes were exposed to X-ray film (Marsh Bio Products) for 13 days at $-80^{\circ} \mathrm{C}$, and quantified as described previously.

\section{Steroid and CAMP assays}

Prior to experiments, cells were washed with $0.01 \mathrm{M}$ PBS and incubated in serum-free media. The additives (stimulators, inhibitors, etc.) were constituted fresh, applied to cells and incubated for different timeperiods as indicated. Accumulation of progesterone in the media was determined by radioimmuno assay (RIA) (Manna et al. 2002b). For assay of cAMP, cells $\left(1 \times 10^{5}\right.$ cells/well in 12-well plates) were treated without or with different factors for $30 \mathrm{~min}$ in the presence of $0.5 \mathrm{mM}$ 3-isobutyl-1-methyl xanthine (IBMX) (Sigma-Aldrich), and the level of intracellular cAMP was determined by RIA (Manna et al. 2006).

\section{Statistical analysis}

Statistical analysis was performed by ANOVA using Statview (Abacus Concepts, Inc., Berkeley, CA, USA) followed by Fisher's protected least significant differences test. All experiments were repeated three to four times as indicated in the figure legends. $P<0 \cdot 05$ was considered statistically significant.

\section{Results}

\section{Role of different factors on StAR, P450scc, 33-HSD, steroid and cAMP levels}

mLTC-1, treated with insulin-like growth factor-I (IGF-I, $100 \mathrm{ng} / \mathrm{ml}$ ), epidermal growth factor (EGF, $10 \mathrm{ng} / \mathrm{ml}$ ), fibroblast growth factor (FGF, $50 \mathrm{ng} / \mathrm{ml}$ ), transforming growth factor $\alpha(\mathrm{TGF} \alpha, 50 \mathrm{ng} / \mathrm{ml})$, interleukin 1 (IL-1, $20 \mathrm{ng} / \mathrm{ml}$ ), colony-stimulating factor-1 (CSF-1, $50 \mathrm{ng} / \mathrm{ml}$ ) and human chorionicgonadotropin (hCG, $50 \mathrm{ng} / \mathrm{ml}$ ) for $6 \mathrm{~h}$ demonstrated increases in StAR protein expression to varying degrees when compared with the controls (Fig. 1A). Maximum effective doses for the factors used were either optimized or based on previous findings (Hales 1992, Saez 1994, Lin et al. 1998, Manna et al. 1999b, 2002a). The magnitude of StAR expression in terms of fold-response over basal was approximately $2 \cdot 7$ with IGF-I, $5 \cdot 4$ with EGF, $1 \cdot 8$ with FGF, $2 \cdot 9$ with TGF $\alpha, 1 \cdot 4$ with IL-1, and 3.0 with CSF-1. Under similar experimental paradigms, phosphorylation of StAR (P-StAR), a requirement indispensable for optimal steroid synthesis (Arakane et al.

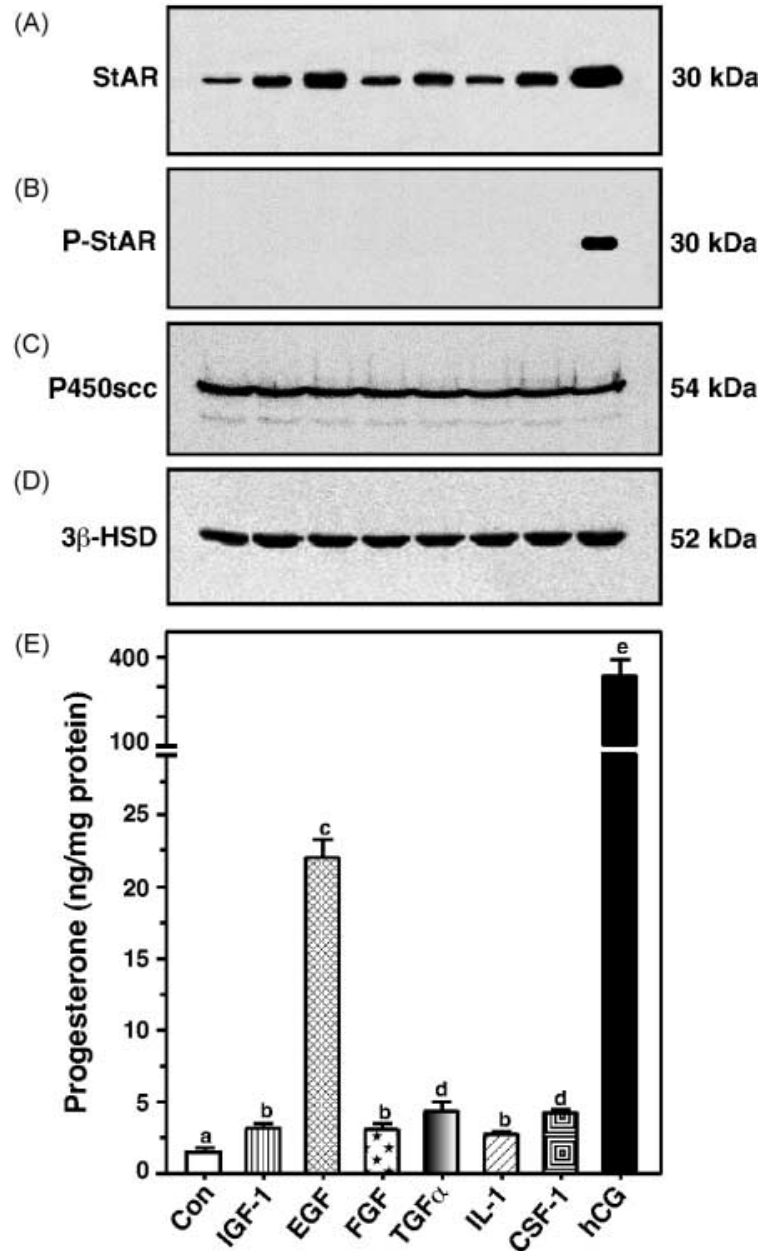

Figure 1 Role of different factors on steroidogenic acute regulatory (StAR), phosphorylation of StAR, P450scc, 3 $\beta$ -

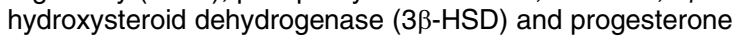
levels in $\mathrm{mLTC}-1$ cells. Cells were treated for $6 \mathrm{~h}$ without (Con), or with insulin-like growth factor-I (IGF-I; $100 \mathrm{ng} / \mathrm{ml}$ ), epidermal growth factor (EGF; $10 \mathrm{ng} / \mathrm{ml})$, fibroblast growth factor (FGF; $50 \mathrm{ng} / \mathrm{ml})$, transforming growth factor $\alpha(\mathrm{TGF} \alpha ; 50 \mathrm{ng} / \mathrm{ml})$, interleukin-1 (IL-1; $20 \mathrm{ng} / \mathrm{ml}$ ), colony-stimulating factor-1 (CSF-1; $50 \mathrm{ng} / \mathrm{ml})$ and human chorionic gonadotropin (hCG) $(50 \mathrm{ng} / \mathrm{ml})$, and subjected to isolation of mitochondria for immunoblotting. Representative immunoblots illustrate expression of (A) StAR, (B) phosphorylation of StAR (P-StAR), (C) P450scc, and (D) 3ß-HSD using $24 \mu \mathrm{g}$ of protein. (E) Accumulation of progesterone in the media of the same treatment groups was determined and expressed as nanogram per milligram protein. Data represent the mean \pm S.E.M. of three independent experiments. Letters above the bars indicate that these groups differ significantly at least at $P<0.05$.

1997, Manna et al. 2006), was undetectable in control, IGF-I, EGF, FGF, TGF $\alpha$, IL-1, and CSF-1-treated cells (Fig. 1B). In contrast, a strong P-StAR signal was observed in response to hCG, which also resulted in a 9-3-fold increase in StAR protein expression over basal. No significant effect of these factors was observed on 


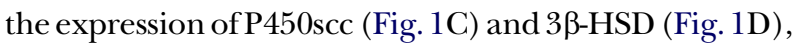
indicating that they increase StAR expression without affecting these enzymes. Progesterone levels in the media in response to IGF-I, FGF, TGF $\alpha$, IL-1, and CSF-1 were lower when compared with StAR expression, being between $1 \cdot 6$ - and 2.8-fold over controls (Fig. 1E). On the other hand, EGF and hCG increased progesterone production by $13 \cdot 6$ - and 188 -fold over basal respectively. These results demonstrate the involvement of StAR phosphorylation-dependent and -independent events in steroid synthesis. In subsequent experiments, a 6-h treatment period and the doses listed previously for the various factors were utilized, unless specified differently.

To affirm or refute the involvement of cAMP on StAR expression and steroidogenesis in response to different factors, the levels of intracellular cAMP were determined. mLTC-1 cells treated for $30 \mathrm{~min}$ with IGF-I, EGF, FGF, TGF $\alpha$, IL-1, and CSF-1 in the presence of $0.5 \mathrm{mM}$ IBMX demonstrated no detectable increase in the levels of cAMP over basal $(0 \cdot 46 \pm 0 \cdot 05 \mathrm{pmol} / 30$ $\mathrm{min} / 10^{5}$ cells) (Table 1 ). While these factors had no effect on basal cAMP by themselves, they enhanced (with the exception of IL-1) hCG-stimulated cAMP synthesis. hCG resulted in an approximately 26-fold increase in cAMP over basal. These findings demonstrate that IGF-I, EGF, FGF, TGF $\alpha$, IL-1, and CSF-1 stimulate StAR expression and steroidogenesis in a cAMP-independent manner in mouse Leydig cells.

The response of StAR mRNA expression to different factors was determined next by RT-PCR analysis. As depicted in Fig. 2A, mLTC-1 cells treated with IGF-I, EGF, FGF, TGF $\alpha$, IL-1, CSF-1, and hCG demonstrated increase in StAR mRNA expression over controls, being approximately $3 \cdot 1$-fold with IGF-I, $6 \cdot 6$-fold with EGF, 2.2-fold with FGF, 3·6-fold with TGF $\alpha, 1 \cdot 6$-fold with IL-1, 3·8-fold with CSF-1, and $10 \cdot 5$-fold with hCG.

Table 1 Effects of different factors on basal and hCG-stimulated cAMP levels. $\mathrm{mLTC}-1$ cells were incubated without or with different factors at indicated concentrations in the presence of $0.5 \mathrm{mM}$ of IBMX, and the level of intracellular cAMP was determined after $30 \mathrm{~min}$. Effects of these factors on hCG $(10 \mathrm{ng} / \mathrm{ml})$ stimulated cAMP levels were also evaluated. Results are the mean \pm S.E.M of three independent experiments carried out in triplicates. Values represent cAMP (pmol/30 $\mathrm{min} / 10^{5} \mathrm{cells}$ )

Basal

hCG

$\begin{array}{lcc}\text { Treatment } & & \\ \text { None } & 0.46 \pm 0.05 & 12 \pm 3 \cdot 4 \\ \text { IGF-I }(100 \mathrm{ng} / \mathrm{ml}) & 0.53 \pm 0.09 & 39 \pm 6 \cdot 5^{\star \star \star} \\ \text { EGF }(10 \mathrm{ng} / \mathrm{ml}) & 0.40 \pm 0.08 & 54 \pm 4 \cdot 7^{\star \star \star} \\ \text { FGF }(50 \mathrm{ng} / \mathrm{ml}) & 0.44 \pm 0.07 & 27 \pm 3 \cdot 3^{\star \star} \\ \text { TGF } \alpha(50 \mathrm{ng} / \mathrm{ml}) & 0 \cdot 39 \pm 0.05 & 48 \pm 6 \cdot 4^{\star \star \star} \\ \text { IL-1 }(20 \mathrm{ng} / \mathrm{ml}) & 0.57 \pm 0.06 & 8 \pm 2 \cdot 1^{\star} \\ \text { CSF-1 }(50 \mathrm{ng} / \mathrm{ml}) & 0.44 \pm 0.06 & 42 \pm 4 \cdot 3^{\star \star \star}\end{array}$

${ }^{\star} P<0 \cdot 05 ;{ }^{*} P<0.01 ;{ }^{\star \star *} P<0.001$ vs hCG.
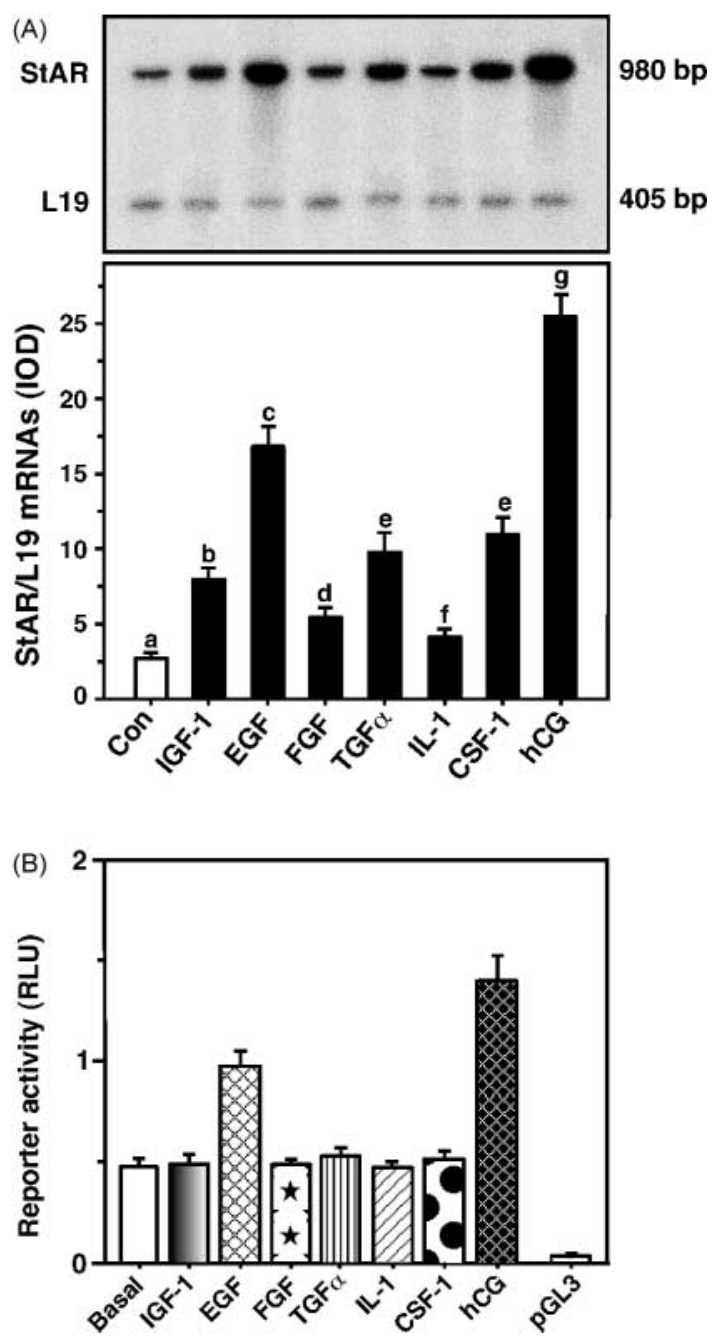

Figure 2 Involvement of different factors in StAR mRNA expression and StAR-promoter activity. $\mathrm{mLTC}-1$ cells were treated for $6 \mathrm{~h}$ without (Con), or with IGF-I, EGF, FGF, TGF $\alpha$, IL-1, CSF-1 and hCG (as described in the legend of Fig. 1). Total RNA was extracted and subjected to RT-PCR analysis of StAR mRNA expression using $2 \mu \mathrm{g}$ of total RNA, as described in Materials and methods. A representative autoradiogram illustrates the expression of StAR mRNA (A) in different treatment groups. Integrated optical density (IOD) values of each band were quantified and normalized with the corresponding L19 bands and presented ( \pm S.E.M., $n=3$ ). mLTC- 1 cells were transfected with the StAR promoter/luciferase construct (-966/-1 StAR-Luc) in the presence of $\mathrm{pRL}$-SV40 (Renilla luciferase for determining transfection efficiency). Following $36 \mathrm{~h}$ of transfection, cells were treated without (basal) or with these factors for $6 \mathrm{~h}$ and luciferase activity in the cell lysates was determined (B). PGL3 basic vector (pGL3) was used as a control. Data represent the mean \pm s.E.M. of three independent experiments. Letters above the bars indicate that these groups differ significantly at least at $P<0.05$.

To determine if these increases in StAR mRNA levels were due to alterations in transcription, cells were transfected with the mouse StAR promoter/reporter segment (-966/-1 StAR-Luc). This segment contains 
several transcription factor recognition motifs and is similar to full-length $(\sim 3.6 \mathrm{~kb})$ promoter responsiveness (Wooton-Kee \& Clark 2000, Manna et al. 2002a). Treatment of transfected cells with IGF-I, FGF, TGF $\alpha$, IL-1, and CSF-1 had no apparent effects on StARpromoter activity (Fig. 2B), suggesting elements responsive to these factors may lie upstream of this segment or in intronic sequences of the gene (King et al. 2004, Manna et al. 2006). In contrast, EGF and hCG showed approximately $1 \cdot 8$ - and $2 \cdot 9$-fold increase $(P<0 \cdot 05)$ in StAR-promoter activity over basal respectively. These results demonstrate that the elevation in StAR mRNA by IGF-I, FGF, TGF $\alpha$, and CSF-1 is independent of an alteration in the rate of StAR gene transcription.

The effect of hCG-stimulated cAMP synthesis on StAR expression and steroid synthesis by cAMP-independent factors was evaluated. Treatment of mLTC-1 cells with a sub-maximal concentration of hCG $(10 \mathrm{ng} / \mathrm{ml})$ resulted in $4 \cdot 6$ - and 82 -fold increase in StAR protein expression and progesterone production over respective controls, and these parameters were increased in the presence of IGF-I, EGF, FGF, TGF $\alpha$, and CSF-1 to varying levels (Fig. 3A). Importantly, while P-StAR was undetectable in response to cAMP-independent factors, they further augmented $(P<0 \cdot 05)$ hCG-induced P-StAR (Fig. 3B) and progesterone (Fig. 3C) levels. In particular, these factors were capable of augmenting hCG-stimulated progesterone levels by IGF-I $(212 \%)$, EGF $(256 \%)$, FGF $(138 \%)$, TGF $\alpha(167 \%)$, and CSF-1 $(141 \%)$. However, marked increase in progesterone synthesis in response to cAMP-idependent factors in the presence of hCG appeared to be closely associated with increase in P-StAR. Conversely, treatment with IL-1 attenuated hCG-induced StAR protein, P-StAR, and progesterone levels (Fig. 3A-C). Treatment of the -966/-1 StAR-Luc transfected cells with hCG (10 ng/ $\mathrm{ml}$ ) in combination with IGF-I, EGF, FGF, TGF $\alpha$, and CSF-1 demonstrated significant increase $(P<0.05)$ in StAR-promoter activity over the response seen with hCG alone (data not shown).

\section{Role of the PKA and PKC pathways on the effects of different factors in progesterone synthesis}

The potential roles of the PKA and PKC pathways in cAMP-independent steroidogenesis in mLTC-1 cells were assessed. Cells treated with IGF-I, EGF, FGF, IL-1, TGF $\alpha$, CSF-1, and hCG demonstrated approximately 2·1-, 13·9-, 1·7-, 1·5-, 2·4-, 2·8-, and 176-fold increase in progesterone synthesis over basal levels (Table 2). Inhibition of PKA activity with the PKA inhibitor H-89 (25 $\mu \mathrm{M}$; (Rao et al. 2003, Manna et al. 2006)) decreased progesterone levels between 34 and $55 \%$ under basal and stimulated conditions, suggesting the involvement of endogenous cAMP in steroidogenesis, since these factors had no effects on cAMP levels. On the other

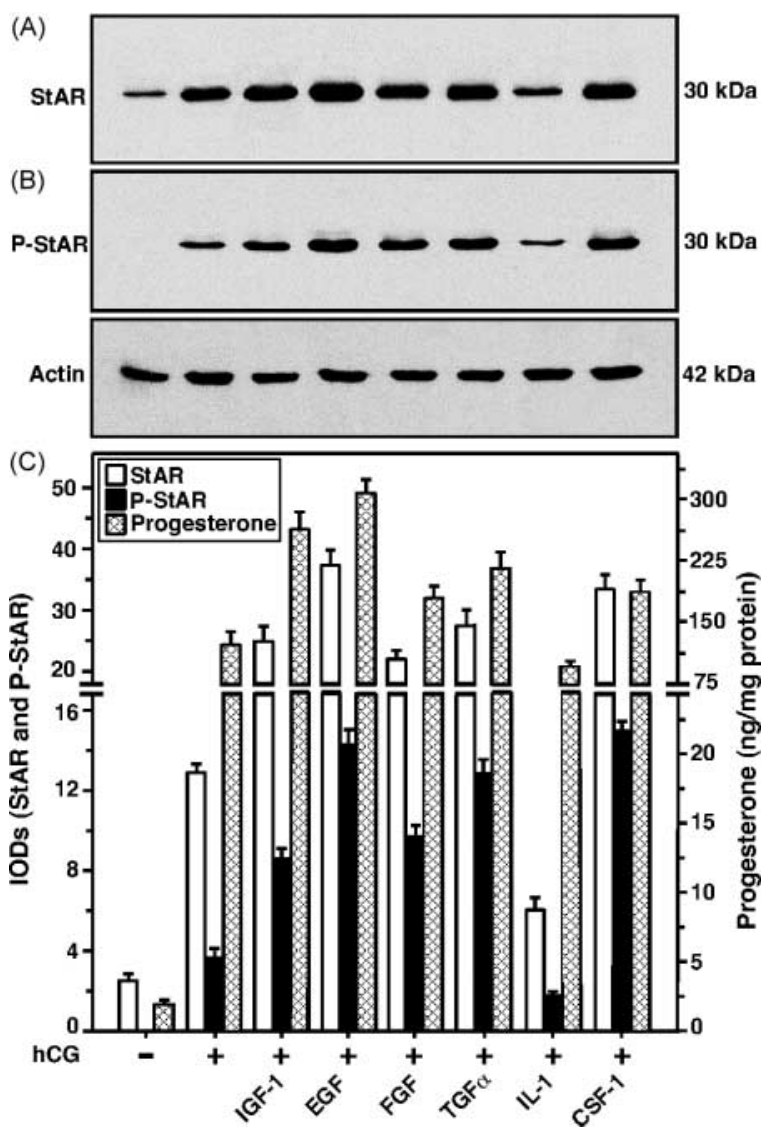

Figure 3 Involvement of different factors in hCG-induced StAR protein, StAR phosphorylation and progesterone levels in $\mathrm{mLTC}-1$ cells. Cells were treated for $6 \mathrm{~h}$ without or with IGF-I, EGF, FGF, TGF $\alpha$, IL-1, CSF-1 (as described in the legend of Fig. 1) and hCG $(10 \mathrm{ng} / \mathrm{ml})$, or their combination as indicated, and mitochondria were isolated for immunoblotting. Representative immunoblots show StAR protein expression (A) and StAR phosphorylation (P-StAR) (B) using $26 \mu \mathrm{g}$ of mitochondrial protein. Expression of actin in the different groups was determined as a loading control (lower panel). IOD values of the bands for StAR and P-StAR were quantified and compiled from three independent experiments and presented $(\mathrm{C})$. Accumulation of progesterone in the media from different treatment groups was determined and expressed as nanogram per milligram protein (C). Data represent the mean \pm S.E.M. of three to four independent experiments. Note the different scales on the graph.

hand, H-89 attenuated hCG-stimulated progesterone synthesis by $86 \%$. Using similar experimental paradigms, cells treated with these agents in the presence of the PKC inhibitor GF-109203X (GFX, $20 \mu \mathrm{M}$; (Jo et al. 2005, Manna et al. 2006)) demonstrated decrease in progesterone synthesis between 33 and $72 \%$. GFX also inhibited hCG-stimulated progesterone production by 26\%. It appears that the PKA and PKC pathways influence cAMP-independent and -dependent steroidogenesis differently, and point to the involvement of cross-talk in these signaling pathways. 
Table 2 Role of the PKA and PKC signaling pathways on progesterone synthesis mediated by different factors in mLTC-1 cells. Cells were pretreated with vehicle or with inhibitors of PKA $(\mathrm{H}-89,25 \mu \mathrm{M})$ and PKC (GF-109203X; $20 \mu \mathrm{M})$ for 20 min. Cells were then incubated without or with different factors at the indicated concentrations for $6 \mathrm{~h}$, and progesterone accumulation in the media was determined. Data represent the mean \pm S.E.M of three independent experiments carried out in triplicates. Values represent progesterone (ng/mg protein)

No inhibitor

H-89(PKA inhibitor)
GF-109203X(GFX)(PKC inhibitor)

\section{Treatment}

None

IGF-I $(100 \mathrm{ng} / \mathrm{ml})$

EGF $(10 \mathrm{ng} / \mathrm{ml})$

FGF $(50 \mathrm{ng} / \mathrm{ml})$

$\mathrm{TGF} \alpha(50 \mathrm{ng} / \mathrm{ml})$

IL-1 $(20 \mathrm{ng} / \mathrm{ml})$

CSF-1 $(50 \mathrm{ng} / \mathrm{ml})$

hCG $(50 \mathrm{ng} / \mathrm{ml})$
$1 \cdot 87 \pm 0 \cdot 16$
$3 \cdot 93 \pm 0 \cdot 24$
$25 \cdot 9 \pm 3 \cdot 6$
$3 \cdot 18 \pm 0 \cdot 26$
$4 \cdot 32 \pm 0.42$
$2 \cdot 62 \pm 0.23$
$5 \cdot 24 \pm 0 \cdot 22$
$334 \pm 26$
$1 \cdot 03 \pm 0 \cdot 09^{*}$
$2 \cdot 26+0 \cdot 14^{*}$
$12 \cdot 64 \pm 3 \cdot 15^{\star}$
$2 \cdot 16 \pm 0 \cdot 19^{*}$
$2 \cdot 45 \pm 0 \cdot 16^{*}$
$1 \cdot 52 \pm 0 \cdot 12^{*}$
$2 \cdot 42 \pm 0 \cdot 18^{\star}$
$47 \pm 8^{\star \star \star}$
$1 \cdot 49 \pm 0 \cdot 11$
$1 \cdot 08+0 \cdot 16^{\star \star \star}$
$17 \cdot 38 \pm 4 \cdot 16^{*}$
$1 \cdot 74 \pm 0 \cdot 13^{\star \star}$
$2 \cdot 69 \pm 0 \cdot 17^{\star}$
$1 \cdot 33 \pm 0 \cdot 15^{*}$
$2 \cdot 12 \pm 0 \cdot 26^{\star \star}$
$251 \pm 14$

${ }^{\star} P<0.05 ;{ }^{* \star} P<0.01 ;{ }^{* \star} P<0.001$ vs respective controls (no inhibitor).

\section{Effects of different factors on MAPK signaling}

To understand potential mechanisms involved in cAMP-independent steroidogenesis, the role of these factors on MAPK was investigated. mLTC-1 cells transfected with a path-detect ElK1 trans-reporting system followed by treatment with IGF-I, EGF, FGF, TGF $\alpha$, IL-1, CSF-1, and hCG demonstrated significant increase $(P<0 \cdot 05)$ in luciferase activity (Fig. 4). The magnitude of the responses were approximately $2 \cdot 6$-, $3 \cdot 4-, 1 \cdot 7-, 2 \cdot 4-, 1 \cdot 9-, 2 \cdot 5-$, and 5·3-fold with IGF-I, EGF,

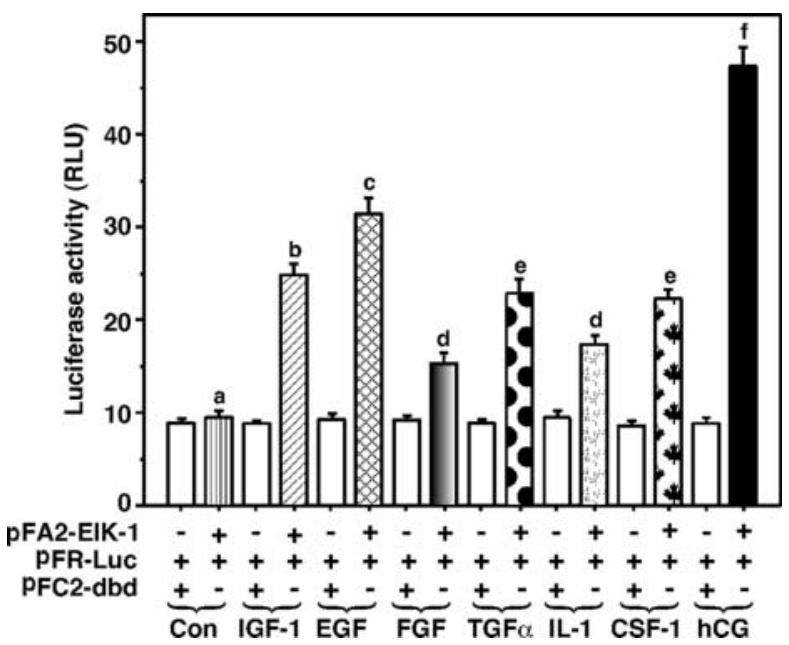

Figure 4 Role of different factors in MAPK signaling. mLTC-1 cells were transfected with the path-detect EIK-1 trans-reporting system as described in Materials and methods. Following $36 \mathrm{~h}$ of transfection, cells were treated without (Con), or with IGF-I, EGF, FGF, TGF $\alpha, \mathrm{IL}-1, \mathrm{CSF}-1$ and hCG (as described in the legend of Fig. 1) for an additional $6 \mathrm{~h}$ and luciferase activity in the cell lysates was determined. Data represent the mean \pm S.E.M. of four independent experiments. Letters above the bars indicate that these groups differ significantly at least at $P<0 \cdot 05$. pFA2-EIK1, pathway-specific trans-activator plasmid fused with the DNA-binding domain (dbd) of yeast Gal4; pFR-Luc, reporter plasmid; pFC2-dbd, negative control of pFA2 plasmid that lacks Elk1.
FGF, TGF $\alpha$, IL-1, CSF-1, and hCG over respective controls, indicating the involvement of these factors in the MAPK pathway.

\section{TGF $\alpha$ signaling in StAR expression and steroidogenesis}

The role of cAMP-independent events in regulating StAR expression and steroidogenesis was further evaluated by studying the TGF $\alpha$ signal transduction pathway in mLTC-1 cells. As depicted in Fig. 5A, cells treated with TGF $\alpha$ demonstrated 2.7- and 2.4-fold increase in StAR protein expression and progesterone production over respective controls. Addition of cycloheximide (Chx, $5 \mu \mathrm{g} / \mathrm{ml}$ ) to TGF $\alpha$-treated cells resulted in decrease in StAR protein and progesterone levels, indicating the requirement for ongoing protein synthesis in TGF $\alpha$-mediated steroidogenic response in these cells.

TGF $\alpha$ is known to bind to the EGFR, hence, the function of this receptor in mLTC-1 cells was determined. The results presented in Fig. 5B show that cells treated with TGF $\alpha$, EGF, and hCG demonstrated significant increase $(P<0 \cdot 01)$ in StAR mRNA expression and progesterone production over basal levels. The addition of a selective inhibitor of EGFR, AG1478, to these treatments markedly decreased TGF $\alpha$ and EGF-stimulated StAR expression and progesterone production, but did not affect hCG-induced responsiveness, indicating that the stimulatory effects of TGF $\alpha$ and EGF are mediated via activation of the EGFR.

Since Leydig cells possess LH/hCG receptors, the effect of TGF $\alpha$ on hCG binding and LHR mRNA expression was analyzed. Following a lag period of 4$6 \mathrm{~h}$, mLTC-1 cells incubated with TGF $\alpha$ for $0-24 \mathrm{~h}$ demonstrated a decrease in $\left[{ }^{125} \mathrm{I}\right]-\mathrm{hCG}$ binding in a temporal manner (Fig. 6A). In fact, a modest increase $(15-20 \%)$ in $\left.{ }^{125} \mathrm{I}\right]-\mathrm{hCG}$ binding was noticed at $4 \mathrm{~h}$, which was followed by a significant decrease $(P<0 \cdot 05)$ 
(A)
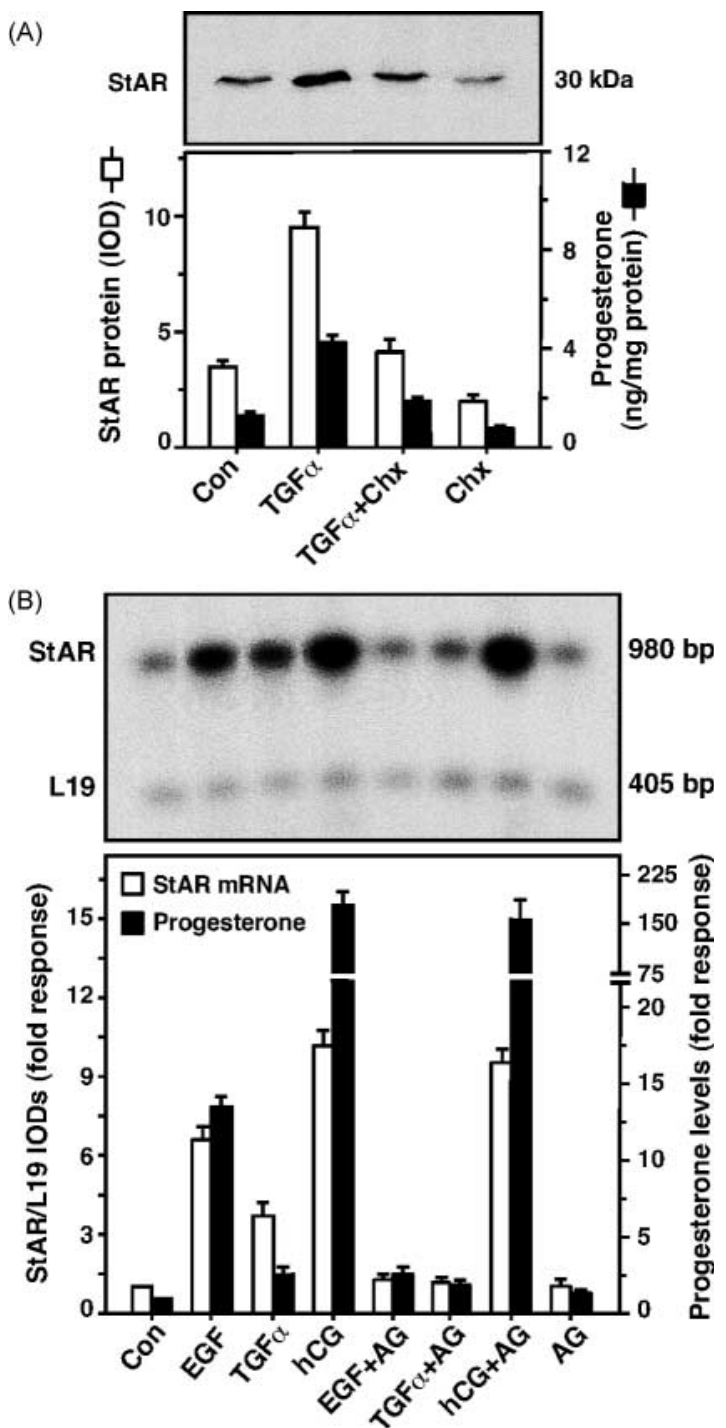

Figure 5 Effect of TGF $\alpha$ on StAR expression and progesterone production, their dependence on ongoing protein synthesis and the relevance of EGFR in TGF $\alpha$ function. $\mathrm{mLTC}-1$ cells were treated for $6 \mathrm{~h}$ without (Con) or with TGF $\alpha(50 \mathrm{ng} / \mathrm{ml})$ in the absence or presence of $\mathrm{Chx}(5 \mu \mathrm{g} / \mathrm{ml})$. Mitochondria from different groups were isolated for immunoblotting, and a representative immunoblot demonstrates the effect of TGF $\alpha$ on StAR protein expression (A). IOD values of each band were quantified and compiled from three independent experiments. Progesterone levels in the media were determined. Panel $B$ illustrates the functional relevance of EGFR in TGF $\alpha$ stimulated StAR mRNA expression and steroid synthesis. Cells were treated without (Con), or with TGF $\alpha(50 \mathrm{ng} / \mathrm{ml})$, EGF $(10 \mathrm{ng} / \mathrm{ml})$ and hCG (50 $\mathrm{ng} / \mathrm{ml})$, in the absence or presence of a specific inhibitor of EGFR, AG1478 (AG, $100 \mathrm{nM}$ ). A representative autoradiogram illustrates the effects of different factors on StAR mRNA expression as determined by RT-PCR analysis. IOD values of each band were quantified and normalized to the intensity of the corresponding L19 bands ( \pm S.E.M., $n=3$ ). Progesterone levels in the media were determined. Data represent the mean \pm S.E.M. of three to five independent experiments. Note the different scales on the graph. at $12 \mathrm{~h}$, and at $24 \mathrm{~h}$, the binding was decreased by $65 \%$. To corroborate the $\left[{ }^{125} \mathrm{I}\right]$-hCG binding in response to TGF $\alpha$, its role on LHR mRNA expression was determined (Fig. 6B). Cells treated with TGF $\alpha$ demonstrated qualitatively similar results as those seen in $\left[{ }^{125} \mathrm{I}\right]$-hCG binding. Northern hybridization analysis with an LHR-specific probe revealed four LHR mRNA transcripts of $6 \cdot 9,2 \cdot 6,1 \cdot 8$, and $1 \cdot 4 \mathrm{~kb}$, and treatment with TGF $\alpha$ decreased all of the transcripts in a coordinate fashion. The decrease in the steady-state levels of LHR mRNA observed with longer periods of TGF $\alpha$ treatment is in agreement with the previous studies using gonadal cells (Wang et al. 1991, Cao et al. 1994, Saez 1994, Lamm et al. 1999, Manna et al. 2002a).

To understand the mechanisms involved in the TGF $\alpha$-mediated steroidogenic response, we investigated the ERK1/2 signaling cascade that functions in StAR expression and steroidogenesis (Gyles et al. 2001, Seger et al. 2001, Manna et al. 2006). Serum-starved mLTC-1 cells treated with TGF $\alpha$ for 0-60 min demonstrated increase in phosphorylation of ERK1/2 (PERK1/2) at $5 \mathrm{~min}(P<0 \cdot 01)$, was maximal at $15 \mathrm{~min}$, and decreased thereafter with time (Fig. 7A). Addition of a MAPK/ERK (MEK) inhibitor U0126 (U0, $12 \mu \mathrm{M}$ ) markedly attenuated TGF $\alpha$-mediated P-ERK1/2. The amount of total ERK1/2 was unaltered during this timecourse. In addition, cells treated with TGF $\alpha$ demonstrated a $2 \cdot 8$-fold increase in StAR protein expression, which was further augmented by $2 \cdot 1$-fold in the presence of U0 (Fig. 7B). U0 alone was found to increase StAR protein levels. However, P-StAR was undetectable in these treatments (Fig. 7C). While U0 was able to increase TGF $\alpha$-stimulated StAR expression, progesterone production was decreased by $36-52 \%$ under basal and stimulated conditions (Fig. 7D). These results demonstrate that $\mathrm{U} 0$ influences StAR expression and steroidogenesis without affecting StAR phosphorylation.

To obtain more insight into these mechanisms, the expression of DAX-1 and SR-B1, the two proteins involved in the steroidogenic process, were analyzed. mLTC-1 cells treated with increasing concentrations of TGF $\alpha(0-300 \mathrm{ng} / \mathrm{ml})$ demonstrated a dose-dependent increase in StAR protein expression (Fig. 8A), which inversely correlated with the expression of DAX-1 (Fig. 8B). No apparent effect of TGF $\alpha$ on the expression of P450scc protein was observed (Fig. 8C). The decrease in progesterone synthesis seen in response to U0 was then investigated by determining the expression of SR-B1, a receptor involved in the uptake of cholesterol for steroid biosynthesis (Fig. 8D,E). It can be clearly seen that constitutive expression of SR-B1 mRNA increased approximately $2 \cdot 3$-fold over basal in response to TGF $\alpha$, and simultaneous incubation with U0 decreased SR-B1 mRNA expression by $45 \%$. Thus, it is probable that the decrease in TGF $\alpha$-mediated progesterone synthesis in 


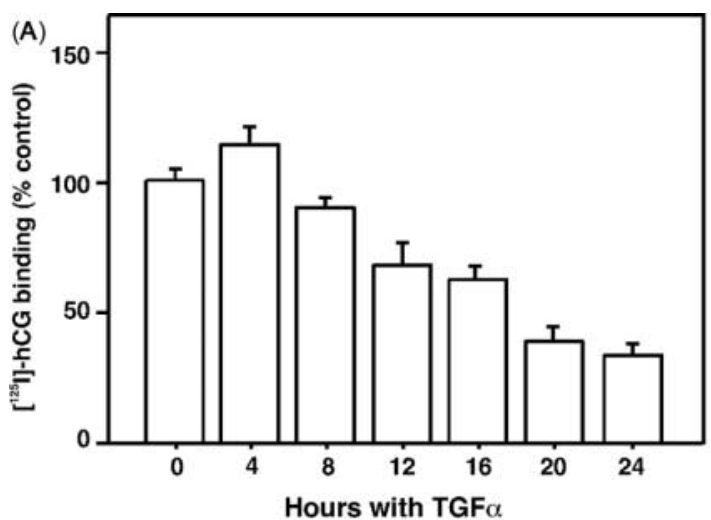

(B)

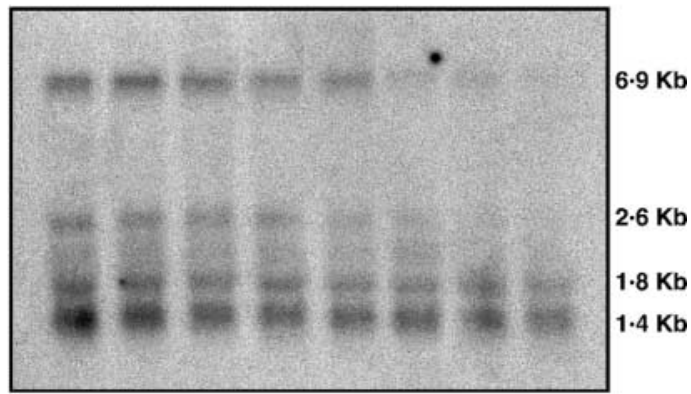

GAPDH

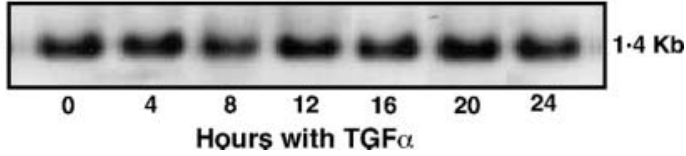

Figure 6 Temporal effect of TGF $\alpha$ on $\left[{ }^{125} \mathrm{I}\right]-\mathrm{hCG}$ binding and LHR mRNA expression in mLTC- 1 cells. Cells $\left(2 \cdot 5-3 \cdot 0 \times 10^{5}\right.$ cells $)$ were incubated without or with TGF $\alpha(50 \mathrm{ng} / \mathrm{ml})$ for $0-24 \mathrm{~h}$ and $\left[{ }^{125} \mathrm{I}\right]$-hCG binding was determined as described in Materials and methods (A). Data represent the mean \pm S.E.M. of three independent experiments. Effect of TGF $\alpha$ on LHR mRNA expression was determined (B). Cells were also treated without or with TGF $\alpha$ $(50 \mathrm{ng} / \mathrm{ml})$ for $0-24 \mathrm{~h}$ and subjected to extraction of total RNA for northern blotting. A cRNA probe for the extracellular segment of the rat LHR (441-849 bp) was used for hybridization using $20 \mu \mathrm{g}$ of total RNA. A representative autoradiogram illustrates the effects of TGF $\alpha$ on LHR mRNA expression. Molecular sizes of different LHR mRNA splice variants $(6 \cdot 9,2 \cdot 6,1 \cdot 8$, and $1 \cdot 4 \mathrm{~kb})$ are indicated on the right. GAPDH mRNA expression in each fraction demonstrates equal loading of RNA (lower panel). Northern blot data are representative of three independent experiments.

the presence of U0 was, at least in part, due to the inhibition of SR-BI expression that would in turn result in insufficient cholesterol availability.

\section{Role of different factors on CREB phosphorylation and its relevance to TGF $\alpha$ responsive StAR gene transcription}

CREB has been shown to be involved in the transcriptional regulation of StAR, a process markedly inhibited by the expression of non-phosphorylatable CREB
(Manna et al. 2002b, 2003). Thus, it was of interest to determine whether cAMP-independent factors play roles in CREB phosphorylation (P-CREB). As illustrated in Fig. 9A, mLTC-1 cells treated with different factors for $30 \mathrm{~min}$ (Clem et al. 2005, Manna et al. 2006), increased P-CREB to varying levels. P-CREB appeared as a doublet and was enhanced approximately $2 \cdot 2-, 3 \cdot 1-$, 1.9-, 2.7-, 1.8-, 2.9- and 4.8-fold over controls in response to IGF-I, EGF, FGF, TGF $\alpha$, IL-1, CSF-1, and hCG respectively. No apparent change was observed in the CREB protein levels. Additionally, cells treated for 30 min with increasing concentrations of TGFa (0$300 \mathrm{ng} / \mathrm{ml}$ ) demonstrated a dose-responsive increase in P-CREB without affecting the amounts of total CREB (Fig. 9B).

The relevance of CREB phosphorylation by TGF $\alpha$ on StAR gene transcription was investigated using a mutant CREB (CREB-M1) in which Ser133 was mutated to Ala $\left(\mathrm{Ser}^{133} \mathrm{Ala}\right)$. mLTC-1 cells co-transfected with wild type (WT)-CREB in the presence of the -966/-1 StAR reporter segment, resulted in 1.6-fold increase in luciferase activity in response to hCG, over the response seen in mock-transfected cells (Fig. 9C). It is noteworthy, however, that while TGF $\alpha$ had no effect on StAR-promoter activity, it significantly increased $(P<$ $0 \cdot 05)$ hCG-stimulated reporter response that could be due to an elevation in cAMP level. Cells transfected with CREB-M1 strongly diminished basal, hCG, and TGF $\alpha$ plus hCG-mediated StAR promoter responses, demonstrating that phosphorylation of CREB is a mechanism involved in cAMP-independent regulation of StAR transcription.

\section{Discussion}

Regulation of the steroidogenic machinery in gonadal cells involves a complex interaction of a diversity of hormones and numerous signaling pathways (Saez 1994, Cooke 1999, Ascoli et al. 2002, Stocco et al. 2005). While $\mathrm{LH} / \mathrm{CG}$ is the major regulator of various Leydig cell functions, including steroidogenesis, there is a large body of evidence indicating that the steroidogenic responsiveness of Leydig cells can also be modulated by circulating peptides and locally produced factors. It has been well documented that the StAR protein regulates steroid biosynthesis by mediating the intramitochondrial transport of cholesterol, the rate-limiting and regulated step in steroidogenesis. cAMP-dependent mechanisms predominantly regulate StAR expression and thus, steroid biosynthesis. However, considerable evidence indicates the presence of a role for cAMP-independent signaling events in steroidogenesis (Cooke 1999, Stocco et al. 2005), and the present studies were aimed at elucidating these 


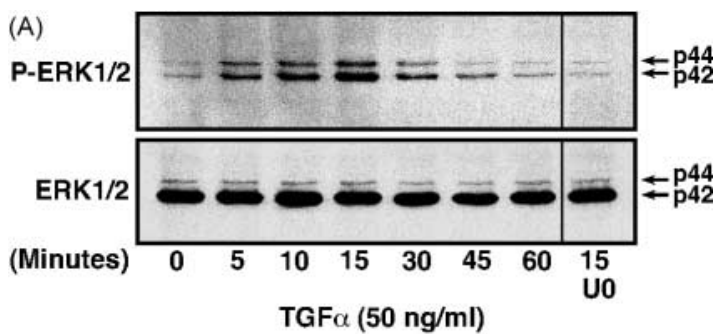

(B)

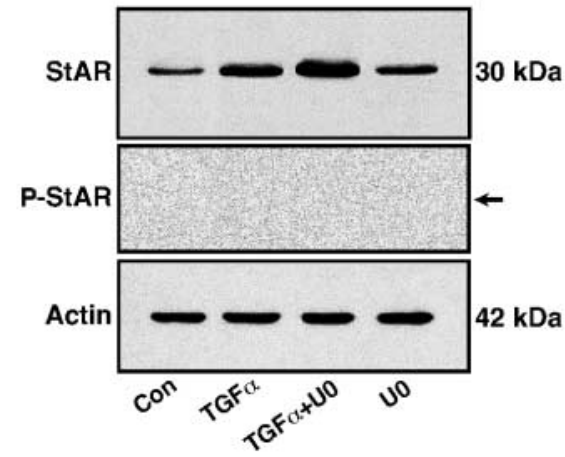

(D)
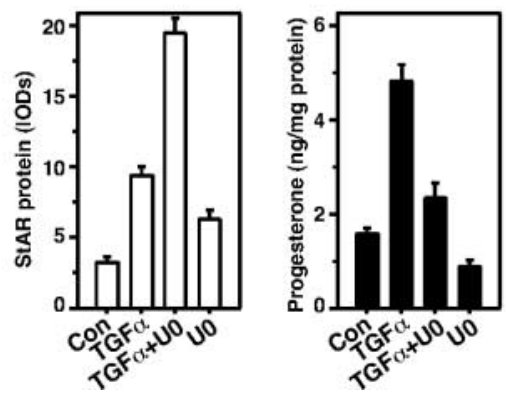

Figure 7 Role of TGF $\alpha$ on ERK1/2 signaling and its relevance to StAR expression and steroid synthesis. $\mathrm{mLTC}-1$ cells were serum starved for $4 \mathrm{~h}$, then pretreated for $15 \mathrm{~min}$ with either vehicle or a MEK inhibitor, U0126 (U0, $12 \mu \mathrm{M})$, and incubated with TGF $\alpha$ (50 ng/ml) for 0-60 min. Phosphorylation of ERK1/2 (P-ERK1/2; p44/p42) and total ERK1/2 (ERK1/2; p44/p42) in the cell lysates (22 $\mu \mathrm{g}$ of protein) were determined by immunoblotting. Representative immunoblots illustrate time response patterns of $P$ ERK1/2 and ERK1/2 (A) in different groups. (B) Cells were also pretreated for 15 min with either vehicle or $\mathrm{UO}$ and then incubated for $6 \mathrm{~h}$ without (Con) or with TGF $\alpha(50 \mathrm{ng} / \mathrm{ml})$ and subjected to isolation of mitochondria for StAR protein expression and StAR phosphorylation (P-StAR) using $25 \mu \mathrm{g}$ of protein. These experiments were repeated three times, and representative immunoblots are shown (B and $\mathrm{C}$ ). Expression of actin in different treatment groups was determined as a loading control (lower panel). IOD values of each StAR band were quantified.

Accumulation of progesterone in the media of these groups was determined and expressed as nanogram per milligram protein (D). Data represent the mean \pm S.E.M. of three independent experiments.

mechanisms in the regulation of StAR expression and steroid synthesis in mouse Leydig cells.

In the present study, a number of extracellular factors were found to stimulate StAR mRNA, StAR protein, and steroidogenesis in a cAMP-independent
(A)

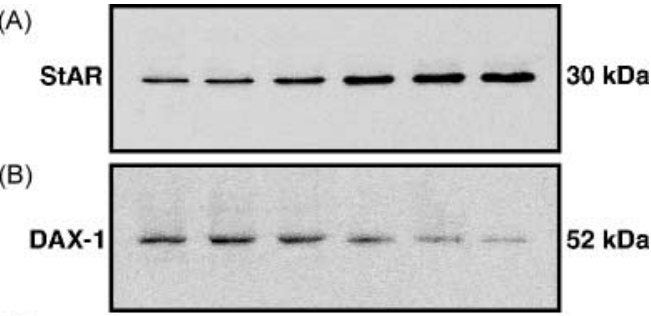

(C)

P450scc

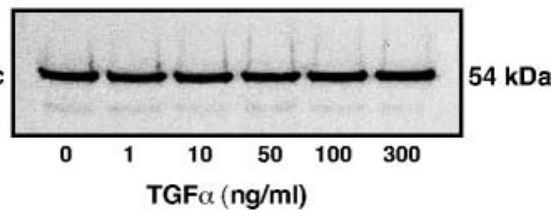

(D)

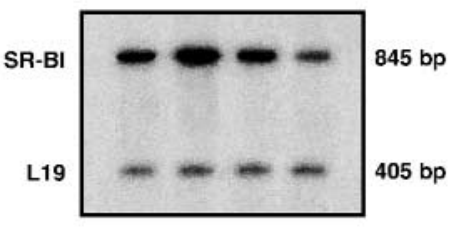

(E)

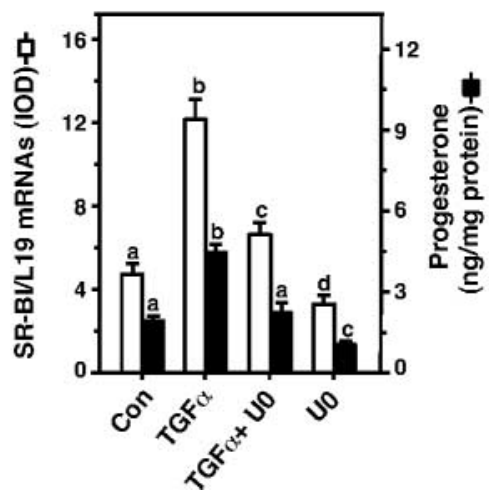

Figure 8 TGF $\alpha$, ERK1/2 and steroidogenesis and their relevance to DAX-1 and SR-BI expression. mLTC-1 cells were treated for $6 \mathrm{~h}$ with increasing concentrations of TGF $\alpha(0-300 \mathrm{ng} / \mathrm{ml})$, and StAR, DAX-1 and P450scc protein expression in the cell lysates (20 $\mu \mathrm{g}$ of protein) were determined by immunoblotting. Representative immunoblots illustrate the dose-response pattern of $\operatorname{StAR}(A)$, DAX-1 (B) and P450scc (C) protein expression. Cells were pretreated for $15 \mathrm{~min}$ with either vehicle or $\mathrm{U} 0126(\mathrm{U} 0,12 \mu \mathrm{M})$, then incubated for $6 \mathrm{~h}$ without (Con) or with TGF $\alpha(50 \mathrm{ng} / \mathrm{ml})$, and subjected to isolation of total RNA for determining SR-B1 mRNA expression by RT-PCR analysis. A representative autoradiogram illustrates the expression of SR-B1 mRNA in the different treatment groups (D). IOD values of each SR-B1 mRNA band were quantified and normalized to the corresponding L19 signals (E). Accumulation of progesterone in the media was determined (E). Data represent the mean \pm S.E.M. of three independent experiments. Letters above the bars indicate that these groups differ significantly at $P<0 \cdot 05$. Note the different scales on the graph.

manner. While it is clear that cAMP-independent effects of various factors on steroidogenesis are quite small when compared with the cAMP-dependent pathway, nevertheless, cAMP-independent pathways could be very important in modulating local regulation of 


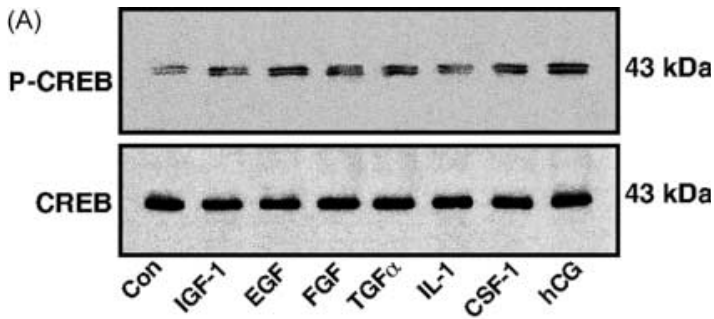

(B)
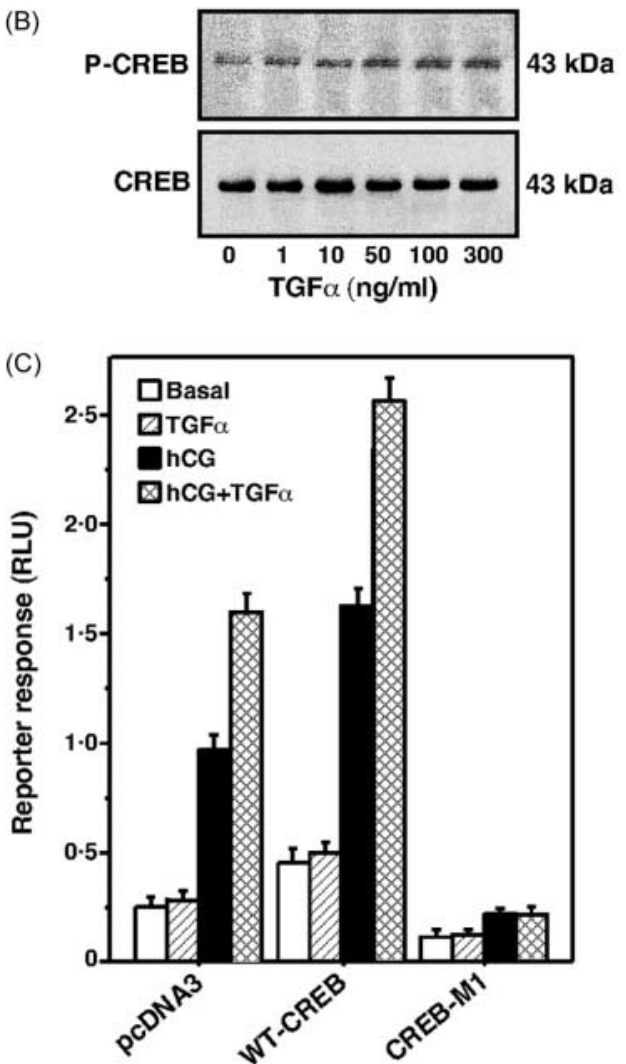

Figure 9 The role of different factors in cAMP-response elementbinding protein (CREB) phosphorylation, and its relevance to TGF $\alpha$ responsive StAR gene transcription. $\mathrm{mLTC}-1$ cells were treated for $30 \mathrm{~min}$ with different factors (as described in the legend to Fig. 1). Phosphorylation of CREB (P-CREB) and total CREB (CREB) in the cell lysates ( $23 \mu \mathrm{g}$ of protein) were determined by immunoblotting $(A)$. Cells were also stimulated with increasing concentrations of TGF $\alpha(0-300 \mathrm{ng} / \mathrm{ml})$, and P-CREB and CREB were determined using $22 \mu \mathrm{g}$ total protein (B). These experiments were repeated three times and representative immunoblots illustrate P-CREB and CREB levels following the different treatments. $\mathrm{mLTC}-1$ cells were also transfected with empty vector (pcDNA3), wild-type CREB (WT-CREB) and non-phosphorylatable CREB (CREB-M1) in the presence of the -966/-1 StAR promoter segment $(C)$. Cells were co-transfected with pRL-SV40 for normalization of transfection efficiency. Following $36 \mathrm{~h}$ of transfection, cells were treated without (basal), or with TGF $\alpha$ (50 ng/ml), hCG $(50 \mathrm{ng} / \mathrm{ml})$ or a combination of them for an additional $6 \mathrm{~h}$ and luciferase activity in the cell lysates was determined. Data represent the mean \pm S.E.M. of four independent experiments. steroid biosynthesis in steroidogenic tissues. Previous studies have demonstrated that phosphorylation of Ser194 of the mouse StAR protein is required for producing optimal levels of steroid synthesis (Arakane et al. 1997, LeHoux et al. 2004). Using a phospho-StAR Ab to Ser194, we observed that none of the cAMPindependent factors were capable of phosphorylating StAR. In contrast, hCG, which primarily exerts its action via cAMP signaling, markedly increased StAR phosphorylation concomitant with steroid production, demonstrating a critical role for phosphorylation in maximally stimulating steroid bisosynthesis (Jo et al. 2005, Manna et al. 2006). As a result, P-StAR is the likely mechanism to explain the dramatic differences observed in steroid synthesis between cAMP-independent and -dependent regulatory events.

cAMP-independent factors (with the exception of IL-1), while unable to enhance intracellular cAMP levels by themselves, were capable of enhancing hCGmediated cAMP levels in mLTC-1 cells. Consequently, in those particular experiments, it is conceivable that marked increase in StAR expression and steroidogenesis by cAMP-independent factors in the presence of hCG could be due to an increase in the levels of cAMP (Stocco et al. 2005, Manna et al. 2006). It is also possible that these factors may play important roles in regulating other testicular/ovarian functions, including developmental processes and reproductive functions (Baker et al. 1996, Pollard 1997, Park et al. 2004, Jamnongjit et al. 2005). In the present findings, no significant effect on the expression of P450scc and $3 \beta-$ HSD in response to these factors was observed. However, studies have demonstrated that many of them were capable of increasing hCG-stimulated P450scc levels (van Haren et al. 1992, Lin et al. 1998, Cooke 1999, Stocco et al. 2005). On the other hand, the inhibition of the hCG-stimulated steroidogenic response by IL-1 can be explained by previous findings that demonstrated a decrease in LHR function and steroidogenic enzymes, including P450scc, P450c17, and 3ß-HSD in Leydig cells (Lin et al. 1991, Hales 1992, Mauduit et al. 1992). Thus, it seems possible that a balance between the positive and negative effects of different factors may allow the fine-tuning of the regulatory events associated with testicular functions.

The involvement of several second messenger systems including the PKA (Balasubramanian et al. 1997, Sekar et al. 2000, Wang et al. 2000) and PKC (Fiedler et al. 1999, Jo et al. 2005, Manna et al. 2006) pathways in the regulation of steroidogenesis have been demonstrated. The present data demonstrate that stimulation of steroidogenesis by factors involving cAMP-independent and -dependent events utilize both PKA and PKC signaling and likely represent cross-talk between the pathways. The observation that inhibition of PKA activity also decreased the steroidogenic response mediated by 
cAMP-independent factors could indicate that the synergistic action of these factors on hCG-stimulated steroidogenesis requires the involvement of endogenous cAMP. The importance of PKA in the ongoing steroid synthesis has recently been demonstrated by using different PKA inhibitors, and reported on a possible mechanism via guanine nucleotide exchange factors for the cross-talk between different signaling pathways in steroidogenic cells (Chin \& Abayasekara 2004). However, it should be taken into account that the results presented here were obtained utilizing an established mouse Leydig cell line and thus, extrapolation of these findings in vivo may not be warranted.

An interesting aspect of the present study is that the regulation of cAMP-independent steroidogenesis does not affect StAR phosphorylation. We did observe that the action of one factor, TGF $\alpha$, in increasing StAR expression and steroid synthesis was dependent on the ongoing protein synthesis. However, the lack of effect of $\mathrm{TGF} \alpha$ (and other specific cAMP-independent factors) on StAR-promoter activity indicates that their effects on the induction of StAR mRNA are independent of an alteration in the rate of StAR gene transcription (Devoto et al. 1999, King et al. 2004, Manna et al. 2006). The marked inhibition of TGF $\alpha$-induced StAR expression and steroid synthesis by AG1478 provided evidence that TGF $\alpha$ stimulates steroidogenesis via activation of the EGFR and reinforces the idea that TGF $\alpha$ and EGF bind to the same receptor (Saez 1994, Schroeder \& Lee 1997). In support of this mechanism, the effects of TGF $\alpha$ and EGF in the regulation of steroidogenic function were demonstrated to be mediated by EGFR in immature rat Leydig cells (Millena et al. 2004). Furthermore, while acute treatment of TGF $\alpha$ in mLTC-1 cells had no apparent effects on $\left[{ }^{125} \mathrm{I}\right]-\mathrm{hCG}$ binding and LHR mRNA expression, its chronic exposure attenuated these responses, an observation consistent with the previous findings with EGF (Wang et al. 1991, Saez 1994, Lamm et al. 1999, Manna et al. 2002a). In addition, longer-term incubation with cAMP-independent factors in mLTC-1 cells was associated with positive (IGF-I and FGF) and negative (EGF, IL-1, and CSF-1) effects on $\left[{ }^{125} \mathrm{I}\right]$-hCG binding and LHR mRNA expression (data not shown).

Conflicting results for the role of the MAPK/ERK signaling cascade in regulating StAR expression and steroidogenesis in different steroidogenic cells have been demonstrated (Gyles et al. 2001, Seger et al. 2001, Tai et al. 2001, Dewi et al. 2002, Manna et al. 2002a, 2006, Seto-Young et al. 2003, Tajima et al. 2003, 2005, Martinelle et al. 2004). For example, inhibition of MAPK/ERK (MEK) activity with PD98059 and U0126 has been shown to be associated with stimulation (Seger et al. 2001, Tajima et al. 2003), inhibition (Gyles et al. 2001, Manna et al. 2002a, Martinelle et al. 2004), or no effect (Tai et al. 2001, Seto-Young et al. 2003, Tajima et al.
2005) on the steroidogenic response. In the present study, different factors were found to stimulate MAPK signaling to various levels as determined using a pathdetect Elk-1 trans-reporting assay. Nevertheless, we demonstrate that the activation of TGF $\alpha$-mediated ERK1/2 phosphorylation was diminished by a MEK inhibitor, U0. However, inhibition of ERK1/2 activity increased TGF $\alpha$-responsive StAR protein expression (but not StAR phosphorylation), and attenuated progesterone synthesis. Consistent with this, inhibition of MEK was demonstrated to enhance basal- and LH-stimulated StAR expression, but attenuate steroid synthesis both in primary and in mouse Leydig tumor cells (Martinat et al. 2005), an observation in agreement with IGF-I responsive steroidogenesis (Manna et al. 2006). MEK inhibition has also been associated with hCG-responsive decrease (Gyles $e t a l$. 2001, Martinelle $e t$ al. 2004) and LH/FSH-mediated increase (Seger et al. 2001, Tajima et al. 2003) in StAR expression and steroid synthesis in gonadal cells. We have previously demonstrated that inhibition of MEK was capable of decreasing EGF- and $(\mathrm{Bu})_{2}$ CAMP-responsive StAR expression and steroid synthesis in mouse Leydig cells (Manna et al. 2002a). In granulosa-lutein cells, LH/hCG-induced steroidogenesis was demonstrated to be unaffected by MEK inhibitors, however, the same inhibitors decreased $(\mathrm{Bu})_{2}$ CAMP-, cholera toxin-, and forskolin-stimulated progesterone synthesis (Dewi et al. 2002). Furthermore, while MEK inhibition has been shown to markedly attenuate IGF-I-induced progesterone production, no apparent effect of this inhibitor was found in insulinstimulated human granulosa cells (Seto-Young et al. 2003). Taken together, these findings demonstrate a complex role for the MAPK/ERK cascade in the regulation of the steroidogenic response that appeared to be dependent on receptor-effector coupling, and is tissue- and stimulus-specific. We also demonstrated that TGF $\alpha$-mediated increase in StAR protein inversely correlated with a decrease in DAX-1 expression when mLTC-1 cells were treated with U0 (Manna et al. 2006). Angiotensin II and cAMP analog-stimulated increase in StAR protein levels have previously been shown to be correlated with decrease in DAX-1 expression in adrenal (Osman et al. 2002) and MA-10 (Jo \& Stocco 2004) cells respectively. Furthermore, inhibition of MEK resulted in an inhibition of SR-B1 expression, an observation in concurrence with our earlier findings that U0 blocked the availability of cholesterol to the mitochondria by inhibiting expression of SR-B1 (Manna et al. 2006). However, the mechanism accounting for the role of U0 in inhibition of SR-B1 mRNA expression in mLTC-1 mouse Leydig cells requires further investigation. Overall, activation of the MAPK/ ERK pathway with different compounds may involve discrete signaling events and may indicate 
the importance of additional factor(s) in the steroidogenic response.

One of the well known downstream targets of PKA, PKC, and other kinases is the activation of CREB and this event has recently been shown to be highly instrumental in the transcriptional regulation of StAR (Manna et al. 2002b, 2006, Rosenberg et al. 2002, Jo et al. 2005). Upon phosphorylation of CREB on Ser133, it then interacts with CRE sequences. While the StAR gene lacks consensus CREs, three highly conserved $5^{\prime}$ CRE half-sites were identified in the proximal region of the StAR promoter and the involvement of CREB in the regulation of StAR transcription was demonstrated unequivocally (Manna et al. 2002b, 2006). In the present study, all the factors studied were capable of phosphorylating CREB. This was further shown in experiments indicating that activation of TGF $\alpha$-mediated phosphorylation of CREB, resulting an increase in StAR gene expression, was effectively inhibited by expression of a non-phosphorylatable CREB, demonstrating the importance of CREB phosphorylation in transcriptional regulation of the StAR gene.

Taken together, these findings provide insight into the mechanisms of cAMP-independent events regulating StAR expression and steroidogenesis that occur in a StAR phosphorylation-independent manner. In the absence of StAR phosphorylation, steroid biosynthesis is moderate when compared with that occurring in the cAMP-dependent pathway, but may account for important mechanisms involved in fine tuning the regulation of steroidogenesis by locally produced factors.

\section{Acknowledgements}

We thank Drs W L Miller, S R King, C R Parker, and P Sassone-Corsi for generous gifts of valuable reagents. This investigation was supported in part by NIH grant HD-17481, and with funds from Grant B1-0028 from the Robert A Welch Foundation. The authors declare that there is no conflict of interest that would prejudice the impartiality of this scientific work.

\section{References}

Arakane F, King SR, Du Y, Kallen CB, Walsh LP, Watari H, Stocco DM \& Strauss JF III 1997 Phosphorylation of steroidogenic acute regulatory protein (StAR) modulates its steroidogenic activity. Journal of Biological Chemistry 272 32656-32662.

Ascoli M \& Segaloff DL 1989 Regulation of the differentiated functions of Leydig tumor cells by epidermal growth factor. Annals of the New York Academy of Sciences 564 99-115.

Ascoli M, Euffa J \& Segaloff DL 1987 Epidermal growth factor activates steroid biosynthesis in cultured Leydig tumor cells without affecting the levels of cAMP and potentiates the activation of steroid biosynthesis by choriogonadotropin and cAMP. Journal of Biological Chemistry 262 9196-9203.
Ascoli M, Fanelli F \& Segaloff DL 2002 The lutropin/choriogonadotropin receptor, a 2002 perspective. Endocrine Reviews 23 141-174.

Baker J, Hardy MP, Zhou J, Bondy C, Lupu F, Bellve AR \& Efstratiadis A 1996 Effects of an Igfl gene null mutation on mouse reproduction. Molecular Endocrinology 10 903-918.

Balasubramanian K, Lavoie HA, Garmey JC, Stocco DM \& Veldhuis JD 1997 Regulation of porcine granulosa cell steroidogenic acute regulatory protein (StAR) by insulin-like growth factor I: synergism with follicle- stimulating hormone or protein kinase a agonist. Endocrinology 138 433-439.

Bose HS, Sugawara T, Strauss JF III \& Miller WL 1996 The pathophysiology and genetics of congenital lipoid adrenal hyperplasia. International Congenital Lipoid Adrenal Hyperplasia Consortium. New England Journal of Medicine 335 1870-1878.

Bose HS, Whittal RM, Baldwin MA \& Miller WL 1999 The active form of the steroidogenic acute regulatory protein, StAR, appears to be a molten globule. PNAS 96 7250-7255.

Cao H, Lei ZM \& Rao CV 1994 Transcriptional and posttranscriptional mechanisms in epidermal growth factor regulation of human chorionic gonadotropin (hCG) subunits and hCG receptor gene expression in human choriocarcinoma cells. Endocrinology 135 962-970.

Caron KM, Soo SC, Wetsel WC, Stocco DM, Clark BJ \& Parker KL 1997 Targeted disruption of the mouse gene encoding steroidogenic acute regulatory protein provides insights into congenital lipoid adrenal hyperplasia. PNAS 94 11540-11545.

Chin EC \& Abayasekara DRE 2004 Progesterone secretion by luteinizing human granulosa cells: a possible cAMP-dependent but PKA-independent mechanism involved in its regulation. Journal of Endocrinology 183 51-60.

Clark BJ, Wells J, King SR \& Stocco DM 1994 The purification, cloning, and expression of a novel luteinizing hormone-induced mitochondrial protein in MA-10 mouse Leydig tumor cells. Characterization of the steroidogenic acute regulatory protein (StAR). Journal of Biological Chemistry 269 28314-28322.

Clark BJ, Soo SC, Caron KM, Ikeda Y, Parker KL \& Stocco DM 1995 Hormonal and developmental regulation of the steroidogenic acute regulatory protein. Molecular Endocrinology 9 1346-1355.

Clem BF, Hudson EA \& Clark BJ 2005 Cyclic adenosine $3^{\prime}, 5^{\prime}-$ monophosphate (cAMP) enhances cAMP-responsive element binding (CREB) protein phosphorylation and phospho-CREB interaction with the mouse steroidogenic acute regulatory protein gene promoter. Endocrinology 146 1348-1356.

Cooke BA 1999 Signal transduction involving cyclic AMP-dependent and cyclic AMP-independent mechanisms in the control of steroidogenesis. Molecular and Cellular Endocrinology 151 25-35.

Cooke BA, Choi MC, Dirami G, Lopez-Ruiz MP \& West AP 1992 Control of steroidogenesis in Leydig cells. Journal of Steroid Biochemistry and Molecular Biology 43 445-449.

Devoto L, Christenson LK, McAllister JM, Makrigiannakis A \& Strauss JF III 1999 Insulin and insulin-like growth factor-I and -II modulate human granulosa-lutein cell steroidogenesis: enhancement of steroidogenic acute regulatory protein (StAR) expression. Molecular Human Reproduction 5 1003-1010.

Dewi DA, Abayasekara DR \& Wheeler-Jones CP 2002 Requirement for ERK1/2 activation in the regulation of progesterone production in human granulosa-lutein cells is stimulus specific. Endocrinology 143 877-888.

Dufau ML 1988 Endocrine regulation and communicating functions of the Leydig cell. Annual Review of Physiology 50 483-508.

Fiedler EP, Plouffe L Jr, Hales DB, Hales KH \& Khan I 1999 Prostaglandin $\mathrm{F}(2 \alpha)$ induces a rapid decline in progesterone production and steroidogenic acute regulatory protein expression in isolated rat corpus luteum without altering messenger ribonucleic acid expression. Biology of Reproduction 61 643-650.

Gyles SL, Burns CJ, Whitehouse BJ, Sugden D, Marsh PJ, Persaud SJ \& Jones PM 2001 ERKs regulate cyclic AMP-induced steroid synthesis 
through transcription of the steroidogenic acute regulatory (StAR) gene. Journal of Biological Chemistry 276

34888-34895.

Hales DB 1992 Interleukin-1 inhibits Leydig cell steroidogenesis primarily by decreasing 17 alpha-hydroxylase/C17-20 lyase cytochrome P450 expression. Endocrinology 131 2165-2172.

van Haren L, Flinterman JF, Orly J \& Rommerts FF 1992 Luteinizing hormone induction of the cholesterol side-chain cleavage enzyme in cultured immature rat Leydig cells: no role of insulin-like growth factor-I? Molecular and Cellular Endocrinology 87 57-67.

Hasegawa T, Zhao L, Caron KM, Majdic G, Suzuki T, Shizawa S, Sasano H \& Parker KL 2000 Developmental roles of the steroidogenic acute regulatory protein (StAR) as revealed by StAR knockout mice. Molecular Endocrinology 14 1462-1471.

Jamnongjit M, Gill A \& Hammes SR 2005 Epidermal growth factor receptor signaling is required for normal ovarian steroidogenesis and oocyte maturation. PNAS 102 16257-16262.

Jo Y \& Stocco DM 2004 Regulation of steroidogenesis and steroidogenic acute regulatory protein in R2C cells by DAX-1 (dosage-sensitive sex reversal, adrenal hypoplasia congenita, critical region on the X chromosome, gene-1). Endocrinology 145 5629-5637.

Jo Y, King SR, Khan SA \& Stocco DM 2005 Involvement of protein kinase $\mathrm{C}$ and cyclic adenosine $3^{\prime}, 5^{\prime}$-monophosphate-dependent kinase in steroidogenic acute regulatory protein expression and steroid biosynthesis in leydig cells. Biology of Reproduction 73 244-255.

King SR, Matassa AA, White EK, Walsh LP, Jo Y, Rao RM, Stocco DM \& Reyland ME 2004 Oxysterols regulate expression of the steroidogenic acute regulatory protein. Journal of Molecular Endocrinology 32 $507-517$.

Laemmli UK 1970 Cleavage of structural proteins during the assembly of the head of bacteriophage T4. Nature 227 680-685.

Lamm ML, Rajagopalan-Gupta RM \& Hunzicker-Dunn M 1999 Epidermal growth factor-induced heterologous desensitization of the luteinizing hormone/choriogonadotropin receptor in a cell-free membrane preparation is associated with the tyrosine phosphorylation of the epidermal growth factor receptor. Endocrinology 140 29-36.

LeHoux JG, Fleury A, Ducharme L \& Hales DB 2004 Phosphorylation of the hamster adrenal steroidogenic acute regulatory protein as analyzed by two-dimensional polyacrylamide gel electrophoreses. Molecular and Cellular Endocrinology 215 127-134.

Lin D, Sugawara T, Strauss JF III, Clark BJ, Stocco DM, Saenger P, Rogol A \& Miller WL 1995 Role of steroidogenic acute regulatory protein in adrenal and gonadal steroidogenesis. Science 267 1828-1831.

Lin T, Wang TL, Nagpal ML, Calkins JH, Chang WW \& Chi R 1991 Interleukin-1 inhibits cholesterol side-chain cleavage cytochrome P450 expression in primary cultures of Leydig cells. Endocrinology 129 1305-1311.

Lin T, Wang D, Hu J \& Stocco DM 1998 Upregulation of human chorionic gonadotrophin-induced steroidogenic acute regulatory protein by insulin-like growth factor-I in rat leydig cells. Endocrine 8 73-78.

Manna PR \& Stocco DM 2005 Regulation of the steroidogenic acute regulatory protein expression: functional and physiological consequences. Current Drug Targets Immune Endocrine $\mathcal{E}$ Metabolic Disorders 5 93-108.

Manna PR, Tena-Sempere M \& Huhtaniemi IT 1999 $a$ Molecular mechanisms of thyroid hormone-stimulated steroidogenesis in mouse leydig tumor cells. Involvement of the steroidogenic acute regulatory (StAR) protein. Journal of Biological Chemistry 274 5909-5918.

Manna PR, Pakarinen P, El-Hefnawy T \& Huhtaniemi IT $1999 b$ Functional assessment of the calcium messenger system in cultured mouse Leydig tumor cells: regulation of human chorionic gonadotropin-induced expression of the steroidogenic acute regulatory protein. Endocrinology 140 1739-1751.
Manna PR, El-Hefnawy T, Kero J \& Huhtaniemi IT 2001 Biphasic action of prolactin in the regulation of murine Leydig tumor cell functions. Endocrinology 142 308-318.

Manna PR, Huhtaniemi IT, Wang XJ, Eubank DW \& Stocco DM $2002 a$ Mechanisms of epidermal growth factor signaling: regulation of steroid biosynthesis and the steroidogenic acute regulatory protein in mouse leydig tumor cells. Biology of Reproduction 67 1393-1404.

Manna PR, Dyson MT, Eubank DW, Clark BJ, Lalli E \& Sassone-Corsi P $2002 b$ Regulation of steroidogenesis and the steroidogenic acute regulatory protein by a member of the cAMP response-element binding protein family. Molecular Endocrinology 16 184-199.

Manna PR, Eubank DW, Lalli E, Sassone-Corsi P \& Stocco DM 2003 Transcriptional regulation of the mouse steroidogenic acute regulatory protein gene by the cAMP response-element binding protein and steroidogenic factor 1. Journal of Molecular Endocrinology 30 381-397.

Manna PR, Chandrala SP, King SR, Jo Y, Counis R, Huhtaniemi IT \& Stocco DM 2006 Molecular Mechanisms of Insulin-like Growth Factor-I Mediated Regulation of the Steroidogenic Acute Regulatory Protein in Mouse Leydig Cells. Molecular Endocrinology 20 262-378.

Martinat N, Crepieux P, Reiter E \& Guillou F 2005 Extracellular signalregulated kinases (ERK) 1,2 are required for luteinizing hormone (LH)-induced steroidogenesis in primary Leydig cells and control steroidogenic acute regulatory (StAR) expression. Reproduction Nutrition Development 45 101-108.

Martinelle N, Holst M, Soder O \& Svechnikov K 2004 Extracellular signal-regulated kinases are involved in the acute activation of steroidogenesis in immature rat Leydig cells by human chorionic gonadotropin. Endocrinology 145 4629-4634.

Mauduit C, Chauvin MA, Hartmann DJ, Revol A, Morera AM \& Benahmed M 1992 Interleukin-1 alpha as a potent inhibitor of gonadotropin action in porcine Leydig cells: site(s) of action. Biology of Reproduction 46 1119-1126.

Millena AC, Reddy SC, Bowling GH \& Khan SA 2004 Autocrine regulation of steroidogenic function of Leydig cells by transforming growth factor-alpha. Molecular and Cellular Endocrinology 224 29-39.

Miller WL \& Strauss JF III 1999 Molecular pathology and mechanism of action of the steroidogenic acute regulatory protein, StAR. Journal of Steroid Biochemistry and Molecular Biology 69 131-141.

Osman H, Murigande C, Nadakal A \& Capponi AM 2002 Repression of DAX-1 and induction of SF-1 expression. Two mechanisms contributing to the activation of aldosterone biosynthesis in adrenal glomerulosa cells. Journal of Biological Chemistry 277 41259-41267.

Panesar NS \& Chan KW 2004 Low temperature blocks the stimulatory effect of human chorionic gonadotropin on steroidogenic acute regulatory protein mRNA and testosterone production but not cyclic adenosine monophosphate in mouse Leydig tumor cells. Metabolism 53 955-958.

Panesar NS, Chan KW \& Ho CS 2003 Mouse Leydig tumor cells produce C-19 steroids, including testosterone. Steroids 68 245-251.

Park JY, Su YQ, Ariga M, Law E, Jin SL \& Conti M 2004 EGF-like growth factors as mediators of $\mathrm{LH}$ action in the ovulatory follicle. Science 303 682-684.

Pilon A, Martin G, Bultel-Brienne S, Junquero D, Delhon A, Fruchart JC, Staels B \& Clavey V 2003 Regulation of the scavenger receptor BI and the LDL receptor by activators of aldosterone production, angiotensin II and PMA, in the human NCI-H295R adrenocortical cell line. Biochimica et Biophysica Acta 1631 218-228.

Pollard JW 1997 Role of colony-stimulating factor-1 in reproduction and development. Molecular Reproduction and Development 46 54-60.

Rao RM, Jo Y, Leers-Sucheta S, Bose HS, Miller WL, Azhar S \& Stocco DM 2003 Differential regulation of steroid hormone biosynthesis in R2C and MA-10 Leydig tumor cells: role of SR-B1-mediated selective cholesteryl ester transport. Biology of Reproduction 68 114-121.

Rebois RV 1982 Establishment of gonadotropin-responsive murine leydig tumor cell line. Journal of Cell Biology 94 70-76. 
Rosenberg D, Groussin L, Jullian E, Perlemoine K, Bertagna X \& Bertherat J 2002 Role of the PKA-regulated transcription factor CREB in development and tumorigenesis of endocrine tissues. Annals of the New York Academy of Sciences 968 65-74.

Saez JM 1994 Leydig cells: endocrine, paracrine, and autocrine regulation. Endocrine Reviews 15 574-626.

Schroeder JA \& Lee DC 1997 Transgenic mice reveal roles for TGF $\alpha$ and EGF receptor in mammary gland development and neoplasia. Journal of Mammary Gland Biology and Neoplasia 2 119-129.

Schwarzenbach H, Manna PR, Stocco DM, Chakrabarti G \& Mukhopadhyay AK 2003 Stimulatory effect of progesterone on the expression of steroidogenic acute regulatory protein in MA-10 leydig cells. Biology of Reproduction 68 1054-1063.

Seger R, Hanoch T, Rosenberg R, Dantes A, Merz WE \& Strauss JF III 2001 The ERK signaling cascade inhibits gonadotropin-stimulated steroidogenesis. Journal of Biological Chemistry 276 13957-13964.

Sekar N, Lavoie HA \& Veldhuis JD 2000 Concerted regulation of steroidogenic acute regulatory gene expression by luteinizing hormone and insulin (or insulin-like growth factor I) in primary cultures of porcine granulosa-luteal cells. Endocrinology 141 3983-3992.

Seto-Young D, Zajac J, Liu HC, Rosenwaks Z \& Poretsky L 2003 The role of mitogen-activated protein kinase in insulin and insulin-like growth factor I (IGF-I) signaling cascades for progesterone and IGFbinding protein-1 production in human granulosa cells. Journal of Clinical Endocrinology and Metabolism 88 3385-3391.

Stocco DM 2002 Clinical disorders associated with abnormal cholesterol transport: mutations in the steroidogenic acute regulatory protein. Molecular and Cellular Endocrinology 191 19-25.

Stocco DM \& Clark BJ 1996 Regulation of the acute production of steroids in steroidogenic cells. Endocrine Reviews 17 221-244.

Stocco DM, Wang X, Jo Y \& Manna PR 2005 Multiple signaling pathways regulating steroidogenesis and steroidogenic acute regulatory protein expression: more complicated than we thought. Molecular Endocrinology 19 2647-2659.
Tai CJ, Kang SK, Choi KC, Tzeng CR \& Leung PC 2001 Role of mitogen-activated protein kinase in prostaglandin $\mathrm{F}(2 \alpha)$ action in human granulosa-luteal cells. Journal of Clinical Endocrinology and Metabolism 86 375-380.

Tajima K, Dantes A, Yao Z, Sorokina K, Kotsuji F, Seger R \& Amsterdam A 2003 Down-regulation of steroidogenic response to gonadotropins in human and rat preovulatory granulosa cells involves mitogen-activated protein kinase activation and modulation of DAX-1 and steroidogenic factor-1. Journal of Clinical Endocrinology and Metabolism 88 2288-2299.

Tajima K, Yoshii K, Fukuda S, Orisaka M, Miyamoto K \& Amsterdam A 2005 Luteinizing hormone-induced extracellularsignal regulated kinase activation differently modulates progesterone and androstenedione production in bovine theca cells. Endocrinology 146 2903-2910.

Wang H, Segaloff DL \& Ascoli M 1991 Epidermal growth factor and phorbol esters reduce the levels of the cognate mRNA for the LH/CG receptor. Endocrinology 128 2651-2653.

Wang X, Walsh LP, Reinhart AJ \& Stocco DM 2000 The role of arachidonic acid in steroidogenesis and steroidogenic acute regulatory (StAR) gene and protein expression. Journal of Biological Chemistry 275 20204-20209.

Wooton-Kee CR \& Clark BJ 2000 Steroidogenic factor-1 influences protein-deoxyribonucleic acid interactions within the cyclic adenosine 3,5-monophosphate-responsive regions of the murine steroidogenic acute regulatory protein gene. Endocrinology 141 $1345-1355$.

Received in final form 2 May 2006

Accepted 9 May 2006

Made available online as an Accepted Preprint 18 May 2006 